\title{
Liability Rules for Constitutional Rights: The Case of Mass Detentions
}

\author{
BY EUGENE KonTOROVICH* \\ George Mason University School of Law
}

\begin{abstract}
Constitutional law assumes that rights should always be protected by property rules- that is, the government can only take them with the individual's consent. This Article extends to constitutional law the insights of Calabresi and Melamed's famous article on property and liability rules. Whether rights should be protected by property rules or liability rules depends on the transaction costs of negotiating a transfer of rights. As transaction costs rise, liability rules become more attractive.

This Article shows that liability rules can have an important role in constitutional law. Using mass detentions in national security emergencies as a case study, it shows that property rule protection of individual rights sometimes leads to perverse and inefficient results. While the government has repeatedly resorted to mass detentions in emergencies, the Court has never blocked such measures. This is a perverse result of constitutional law's insistence on property rule protection even when transaction costs of transferring liberty rights become extraordinarily high. Holding that a policy violates rights would require, under a property rule, enjoining potentially vital security measures. The Court is unwilling to impose such costs on society. Thus it simply avoids finding that mass detentions violate rights. This creates large groups of uncompensated victims, who are often members of vulnerable ethnic minorities. It also stunts and distorts the development of constitutional law.
\end{abstract}

Switching to liability rules in mass detention situations can, counterintuitively, result in greater redress for detainees, as well deterring detentions and preserving the integrity and predictability of substantive law. Furthermore, the transaction cost analysis developed in this Article has implications that extend beyond mass detentions to a variety of other constitutional contexts.

\footnotetext{
* Assistant Professor, George Mason University School of Law. Email: ekontoro@ gmu.edu.

The author thanks Abraham Bell, Jack Goldsmith, Bruce Johnsen, Nelson Lund, Ariel Porat, Richard Posner, and participants in the Levy Workshop at George Mason and the Legal Scholarship Workshop at the University of Chicago Law School for their thoughtful comments and advice. This Article benefited from the financial support of George Mason's Critical Infrastructure Protection Project and the Law and Economics Center, and helpful research assistance from Sarah Zaffina.
} 


\section{LIABILITY RULES FOR CONSTITUTIONAL RIGHTS: THE CASE OF MASS DETENTIONS}

\section{TABLE OF CONTENTS}

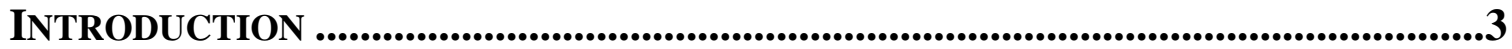

I. THE CONSTITUTIONAL CATHEDRAL.............................................................10

A. Liability and Property Rules........................................................................... 10

1) Rights and remedies distinguished. ............................................................. 10

2) Centrality of transaction costs..................................................................... 12

3) Unified framework of analysis..................................................................... 14

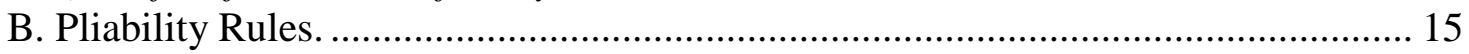

C. Is Constitutional Law Outside The Cathedral? ...................................................... 17

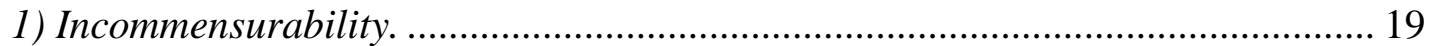

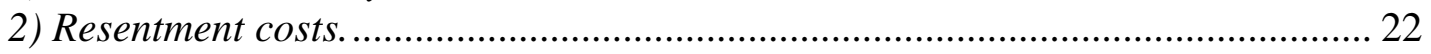

3) Government as imperfect agent....................................................................... 24

II. Pliability Rules for MASS Detentions ........................................................25

A. Judicial Tolerance of Mass Detentions.......................................................... 27

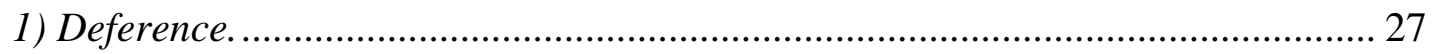

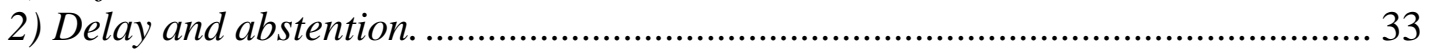

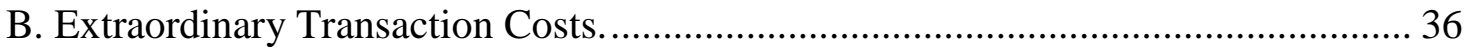

C. Introducing the Mass Detention Pliability Rule....................................................... 39

III. SUPERIORITY OF CONSTITUTIONAL PLIABILITY RULES ...................................43

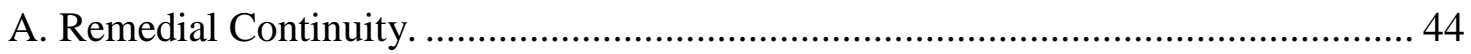

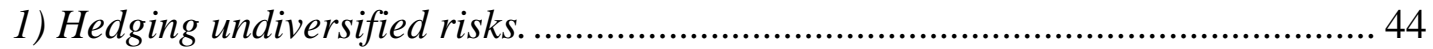

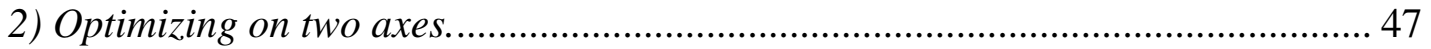

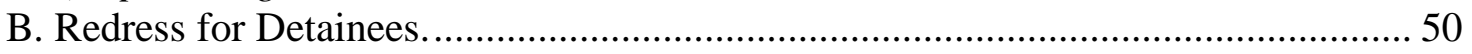

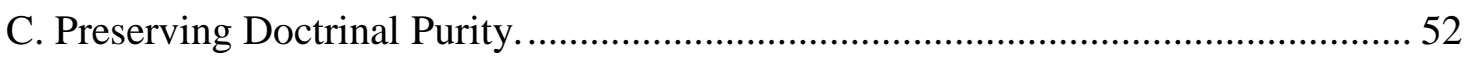

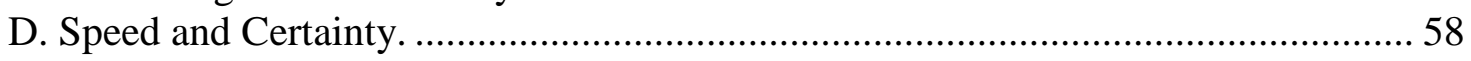

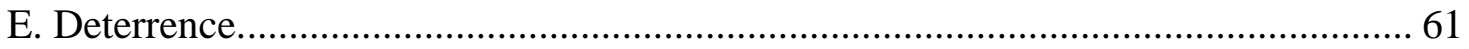

IV. CONSTITUTIONALITY OF LIABILITY RULES ................................................64

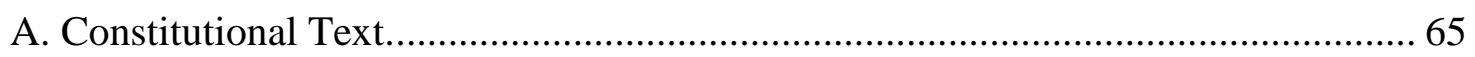

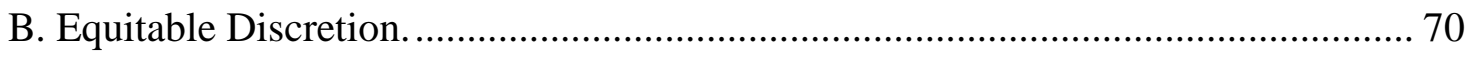

C. Legislative Restrictions on Equitable Relief............................................................ 71

1) The obscure origins of injunctive essentialism.................................................. 71

2) Tax Injunction Act ......................................................................................... 73

3) Summary: a taxonomy of remedial discretion.................................................... 76

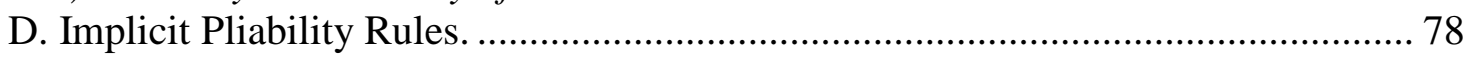

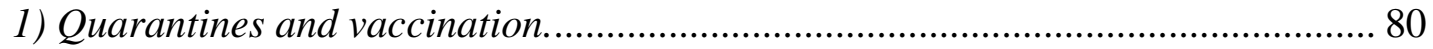

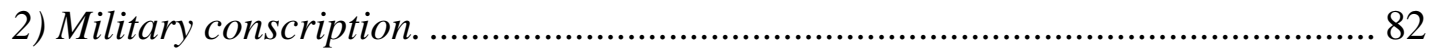

3) Transaction cost limits of the conscription analogy........................................... 85

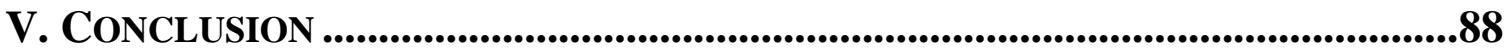




\section{INTRODUCTION}

In the wake of a massive attack on U.S. soil, the government quickly detains thousands of people in the hopes of preventing further strikes. The arrestees are not selected on the basis of individualized suspicion but simply because they share certain ethnic or ideological characteristics with the attackers. As a result, the detention sweeps in many innocent people along with — if successful — the few that are planning havoc.

A court reviewing the detention program faces a stark choice. It can decide that the mass detention policy violates constitutionally protected rights. This would require enjoining the policyand freeing all the de tainees — including the unidentifiable few who may be planning terrorist attacks. Or the court can uphold the detentions, ruling that the individuals' liberty rights must give way to pressing security concerns. Under this scenario, many innocent people remain in jail on the basis of evidence that would normally not even warrant their arrest.

In practice, the Supreme Court has always taken the latter course, placing security interests ahead of liberty interests. This creates classes of entirely uncompensated victims, often politically vulnerable members of ethnic minorities. Furthermore, the doctrinal expedients to which courts resort to avoid enjoining mass detentions distort and stunt constitutional law.

Courts have been unable to vindicate constitutional liberty interests during national security crises because of an overly narrow conception of the legitimate remedies for violations of constitutional rights. This Article, drawing on insights into remedial alternatives from private law, shows that binary choice described above is a false dichotomy. It suggest ways that courts can provide redress for mass detentions 
without compromising vital security interests. It also points toward a richer understanding of the relationship between constitutional rights and remedies.

The liberties set out in the first eight amendments of the Constitution are generally regarded as property rights that must be protected by property rules. This Article will refer to this dominant paradigm as the "injunctive essentialist" paradigm. ${ }^{1}$ An individual threatened by a prospective or ongoing nonconsensual taking of her constitutional rights should be entitled to an injunction against the government. ${ }^{2}$ In this paradigm, money damages only have a role when it is too late for an injunction.

In private law, the situation is quite different. The creation of a legal right leaves open the question of how it will be protected - either through property rules or liability rules. In their path-breaking article, Property Rules, Liability Rules, and Inalienability Rules: One View of the Cathedral ("The Cathedral"), ${ }^{3}$ Calabresi and Melamed ("C\&M") show that the choice of protective rule should hinge on the transaction cost structure under which potential transfers of the entitlement occur. With low transaction costs, property rules - which allow an entitlement to be transferred only when their original

\footnotetext{
${ }^{1}$ This term echoes the "rights essentialism" criticized in Daryl J. Levinson, Rights Essentialism and Remedial Equilibration, 99 COLUM. L. REv. 857, 858-59 (2002) [hereinafter Levinson, Rights Essentialism] (criticizing constitutional theory for viewing rights as fundamentally detached from, and more important than, remedies).

${ }^{2}$ See, e.g., Bell v. Hood, 327 U.S. 678, 684 (1946) ("It is established practice for this Court to sustain the jurisdiction of federal courts to issue injunctions to protect rights safeguarded by the Constitution.") (citing cases); United States v. Stanley, 483 U.S. 669, 690 (1987) (Brennan, J., concurring in part, dissenting in part) ('[C]onstitutional violation[s] may be enjoined if and when discovered.') (dictum); Bivens v. Six Unknown Named Federal Agents, 403 U.S. 388, 404 (1977) (Harlan, J., concurring) (observing the "presumed availability of federal equitable relief against threatened invasions of constitutional interests."); Davis v. District of Columbia, 158 F.3d 342, 1346 (D.C. Cir. 1998) ("[T]here is a presumed availability of federal equitable relief against threatened invasions of constitutional interests."); Ashutosh Bhagwat, Hard Cases and the (D)Evolution of Constitutional Doctrine, 30 ConN. L. REv. 961, 1008 \& n.205 (1998) ("In constitutional law...equitable relief has become the standard remedy for most constitutional violations, and one which is available essentially as a matter of right.").

${ }^{3}$ Guido Calabresi \& A. Douglas Melamed, Property Rules, Liability Rules, and Inalienability Rules: One View of the Cathedral, 85 HARV. L. REV. 1089 (1972).
} 
owner consents - achieve the best results. However, as transaction costs rise, property rules tend to block socially beneficial transactions. Thus, liability rules - which allow entitlements to be transferred against the wishes of their original owners, who then receive money damages - become attractive alternatives.

Constitutional law has ignored the possibility of protecting rights with liability rules. However, no constitutional provision or doctrine explicitly mandates property rules. Indeed, the Constitution is sensitive to the inefficiencies that can be caused by high transaction costs. The Takings Clause prescribes liability rules as the exclusive form of protection in eminent domain cases because under a property rule holdout problems among property owners (a form of transaction cost) would block many socially beneficial government projects. ${ }^{4}$ This Article showsthat the Takings Clause deals with the m ost routine situation where liability rules can be useful for protecting constitutional rights but not the only such situation.

This Article challenges injunctive essentialism by extending the insights of The Cathedral to constitutional law. In some unusual but extraordinarily important situations liability rules may be preferable to property rule protection. Liability rules will be the best way to protect constitutional rights under the same conditions that make them desirable in private law — where enormous transaction costs would prevent socially beneficial rights-transfers under a property rule.

\footnotetext{
${ }^{4}$ U.S. CONST., amend. V. At least one court has characterized Fifth Amendment rights in The Cathedral terms:

There is a fundamental conceptual difference between a takings claim and a substantive due process claim. If the government pays just compensation, it may take property for public use under the Takings Clause. Due process protections, by contrast, define what the government may not require of a private party at all. It is the difference between a liability rule and a property rule.
}

Unity Real Estate Co. v. Hudson, 178 F.3d 649, 658-59 (3rd Cir. 1999) (Becker, C.J.). 
Applying C\&M analysis to constitutional law requires close scrutiny of transaction costs. These costs vary greatly across different factual contexts. Thus this Article focuses on mass detentions in national security emergencies as a concrete example of how the reigning pure property rule paradigm breaks down when transaction costs suddenly rise, and how a switch to liability rules can actually result in greater protection of constitutional rights. Focusing on one particular context allows for a thorough examination of the relevant transaction costs. Mass detentions are, of course, a particularly pertinent case study. They are a reoccurring feature of American history, whose handling by the courts is widely regarded as unsatisfactory. (There are important differences between past mass detentions, but for convenience this Article refers to them generically as "mass detentions" or simply "detentions.") And as a result of the ongoing war on terror, the courts may have to confront this issue again in the near future.

Under the liability rule approach to rights in mass detention situations, courts would not need to make the binary choice between upholding detentions or enjoining them, between mass release or uncompensated mass detention. Rather, upon finding a detention program unconstitutional, courts would refuse to enjoin it and instead award money damages to the detainees for the duration of their confinement. This is, in essence, a Takings Clause approach to non-property rights. Such an approach might seem less protective than the traditional property-rule understanding of constitutional rights. However, this does not take into account the dynamic and complex relationship between rights and remedies. The Cathedral shows that given high transaction costs, property rules can prevent socially beneficial activities. When the cost of foregoing such activities is particularly high, the Supreme Court is unwilling to impose them on society. 
In particular, the Court has been unwilling to enjoin mass detentions during security crisis. Instead, it denies the existence of the right - which under a property rule is the only alternative to issuing an injunction. Constitutional law's insistence on the "stronger" remedy can perversely lead the Court to deny any remedy in certain important cases. Money damages will be more protective of individual rights in such situations: instead of being held without charges and without compensation, detainees would at least enjoy some recovery. Furthermore, the intermediate option of money damages would make courts more willing to find detentions unconstitutional in the first place, thus giving detainees a clear judicial declaration that they have been wronged by the government. This Article does not argue that constitutional rights should at all times be protected by liability rules. ${ }^{5}$ Indeed, property rule protection is normally proper because in run-of-the-mill cases, transaction costs are relatively low. Recognizing that property rules will normally be appropriate for constitutional rights, this Article proposes a remedial structure that would capture both the benefits of property rule protection in the general run of cases with the benefits of liability rules in high transaction cost situations. This remedial structure is a "pliability rule" - it provides property rule protection most of

\footnotetext{
${ }^{5}$ The pure property rule paradigm applies a fortiori to the structural constitution, that is, the constitutional framework that limits the powers of the federal government with respect to other parts of the government and with respect to states. For an interesting example, see Daryl J. Levinson, Making Government Pay: Markets, Politics, and the Allocation of Constitutional Costs, 67 U. CHI. L. REV. 345, 358 n.43 (2000) [hereinafter Levinson, Making Government Pay] ("anticommandeering entitlement is protected not by a liability rule but a property rule, which in effect forces the federal government to buy states' consent to implement federal policies at a mutually agreed upon price."). This Article deals solely with takings of individual liberty by the government and so does not consider remedies for violations of the structural constitution. Liability rules appear to be inapplicable in the latter context. It is not clear how money damages would remedy violations of the structural constitution because the government and its branches does not experience utility. Thus it is not clear how monetary compensation could help make it whole, or even to whom such damages would be paid. And while "constitutional torts" often have common law tort analogs, such as unlawful imprisonment for mass detentions, there are neither market proxies nor tort analogs for violations of the structural constitution. This would make assessing damages even harder than for violations of constitutional individual rights.
} 
the time but liability rule protection some of the time. ${ }^{6}$ The constitutional pliability rule introduced in thisArticle would temporarily toggle the prot ection of liberty rights from a property rule to a liability rule during national security emergencies.

Constitutional pliability rules have attractive features regardless of whether one evaluates a legal rule by its advancement of individual justice, social efficiency, or doctrinal purity. While much of the discussion herein uses the utilitarian language of social efficiency typical of transaction cost analysis, this Article is not insensitive to broader notions of justice. Thus it should appeal to those who believe - in the tradition of The Cathedral itself — that the choice of protective rule should reflect both social efficiency and "other justice" concerns such as distributional effects.

The implications of the transaction cost analysis developed in this Article extend beyond mass detentions. It opens the way for a unified understanding of areas of constitutional jurisprudence that have previously been regarded as unconnected, ad hoc exceptions. Some of these, like quarantines and military conscription, will be discussed at some length, but this Article does not pretend to exhaust the possibilities of C\&M analysis in constitutional law.

The discussion of liability and pliability rules leads to the subsidiary theoretical theme of this Article - the dynamic relationship between constitutional rights and remedies. Injunctive essentialism makes constitutional remedies inflexible: it insists on property rules as the only possible type of protection. Without remedial flexibility, courts wishing to achieve a particular balance of constitutional interests and other interests must

\footnotetext{
${ }^{6}$ The term was first introduced and elaborated in Abraham Bell \& Gideon Parchomovsky, Pliability Rules, 101 MiCH. L. REV. 1, 5 (2002).

${ }^{7}$ See Calabresi \& Melamed, supra note __, at 1104-05, 1121.
} 
introduce flexibility on the front-end, by "flexing" the definition of substantive rights. The broader range of protective rules suggested by The Cathedral gives courts flexibility on the second axis - remedies. This both alleviates harmful pressures on the substantive axis and allows for a more fine-tuned accommodation of conflicting interests.

Part I describes The Cathedral's transaction cost analysis and its implications for the choice between liability and property rules. It then explains the pliability rules, showing how they are well-suited to constitutional law, where optimal protection requires alternating between property rules and liability rules. It concludes by showing that the Cathedral's insights can in fact be translated to constitutional law, and thus there is some role for liability rules in the constitutional context.

Parts II and III focus on mass detentions. Part II shows how courts have not found detentions unconstitutional. It discusses the heightened transaction costs in national security emergencies, and shows how they can make property rules inefficient. Thus the court's denial of any relief in mass detention cases is an artifact of the injunctive essentialist paradigm. Part II concludes by suggesting an alternative - a temporary switch to liability rules for mass detentions during security crises. Part III shows how this pliability rule would function better than the current pure property rule. Finally, Part IV tackles injunctive essentialism on its own territory. It shows that neither constitutional text nor Supreme Court precedent requires property rule protection for rights, or bars liability rule protection. Moreover, it shows that several existing constitutional doctrines can be understood as "implicit" pliability rules. 


\section{THE CONSTITUTIONAL CATHEDRAL}

This Part establishes the conceptual framework of the Article by introducing the transaction cost analysis of The Cathedral and the newer concept of pliability rules. The Cathedral has inspired a corpus of scholarship too vast to be reviewed here. ${ }^{8}$ Instead, Part I.A. summarizes t The Cathedral's major insights, paying particular attention to its applicability to constitutional entitlements. Part I.B introduces pliability rules, a recent refinement thatmakes the $\mathrm{C} \& \mathrm{M}$ framework easier to apply to constitutional rights . Part I.C challenges conventional wisdom that constitutional rights are inherently property rights, and thus immune to $\mathrm{C} \& \mathrm{M}$ analysis. That Part considers the specific objections to and difficulties of protecting constitutional entitlements with liability rules. It finds that liability rules for constitutional rights have drawbacks that make property rules preferable in the kinds of situations courts most often encounter. However, the costs of liability rules are not always prohibitive. To the contrary, property rule protection sometimes has undesirable consequences that make liability rules seem attractive in comprison .

\section{A. Liability and Property Rules.}

1) Rights and remedies distinguished.

The Cathedral disaggregates two aspects of all legal rights: the assignment of an entitlement to one party or another, and the way in which the entitlement can be transferred from the original owner to other parties. Entitlements can be positive or

\footnotetext{
${ }^{8}$ See Bell \& Parchomovsky, supra note___, at 4 (describing The Cathedral literature as "vast" and citing many articles). For excellent summaries and syntheses of The Cathedral and subsequent contributions, see id. at 11-25 and Carol M. Rose, The Shadow of the Cathedral, 108 YALE L.J. 2175 (1997).
} 
negative, narrow or wide. The right to be free of certain physical injuries is an example of an entitlement; the right to keep noxious discharges from invading one's land can be an entitlement, and so is the right to spew noxious discharges from one's factory. Amost all constitutional entitlements are negative - rights to be free of various governmental interferences. Almost all entitlements held by the government are positive - rights to regulate commerce, to tax, to spend, and so forth.

With the entitlement established and assigned, an equally important set of "second order decisions" must be made about the manner in which it may be transferred. ${ }^{9}$ The Cathedral describes three types of protections: property rules, liability rules, and inalienability rules. These rules correspond to different remedies available for violations of the right. Property rules are enforced through injunctions, which use the government's coercive power to prevent nonconsensual takings. As a result, under a property rule the entitlement can only be transferred at a price agreed to by the initial entitlement holder. Liability rules are enforced through ex post damages. They allow the entitlement to be taken by whoever is willing to pay the judicially-determined value of the entitlement, and thus, do not require the consent of the original entitlement-holder. This Article will use the terms "property rules" interchangeably with "injunctive relief," and liability rules interchangeably with “damages.” Inalienability rules prevent the original entitlement holder from voluntarily transferring the entitlement, but also prevent prospective rightstakers from taking it with or without the right-holder's consent. Thus both parties could be enjoined from transferring the entitlement. ${ }^{10}$ Finally, in constitutional law, the concept

\footnotetext{
${ }^{9}$ Calabresi \& Melamed, supra note _, at 1092.

${ }^{10}$ Inalienability rules exist in constitutional law, but they are the exception and property rules the norm. See Thomas W. Merrill, The Constitution and the Cathedral: Prohibiting, Purchasing, and Possibly Condemning Tobacco Advertising, 93 Nw. U. L. REV. 1143, 1150, 1152 (1999). For example, the $13^{\text {th }}$
} 
of a "police power rule" is useful. ${ }^{11}$ Under a police power rule, the government can take a constitutional right without consent or compensation. ${ }^{12}$

\section{2) Centrality of transaction costs.}

Property rules work better than their alternatives when transfers of the entitlement -- from buyer to seller -- face low transaction costs and there are no other market imperfections. Property protection relies on parties' own valuations of entitlements, ensuring that the rights will wind up with the highest-value user. However, as transaction costs increase, the virtues of property rules disappear, leaving only vices. Transaction costs can prevent socially efficient (and even mutually beneficial) entitlement transfers. When such costs frustrate private negotiation, a strict requirement of consent would "preclude many activities that might . . . be worth having." ${ }^{13}$ In such situations, liability rules become more attractive because they allow the entitlement to be coercively transferred by the "buyer" without any preliminary bargaining. Liability rules are something of an end-run around transaction costs.

Amendment's ban on "involuntary servitude" and the right to vote are both enforced through inalienability rules: one cannot sell oneself into slavery or sell one's right to vote. The doctrine of unconstitutional conditions expresses a pseudo-inalienability rule: it bars alienability only under certain circumstances.

This Article will not discuss inalienability rules further. The entitlements dealt with herein are generally alienable under property rules, and this Article argues that sometimes property rule protection restricts rights transfers too tightly. Thus the objections to property rules for constitutional entitlements apply $a$ fortiori to inalienability rules, which totally ban transfers of rights.

${ }^{11}$ See Merrill, supra note _, at 1151-52. This term will not be found in the standard C\&M account that focuses on transactions between private parties. However, it roughly corresponds to C\&M's "Rule Three," under which a nuisance-maker is protected by a property rule, which means the victim of the nuisance receives no protection. See Calabresi \& Melamed, supra note _, at 1116. The nuisance victim is the counterpart of the private citizen whose entitlement is trumped by a governmental need under a police power rule. This Article uses the latter term rather than "Rule Three" because it better captures the relation between governmental power and individual rights.

${ }^{12}$ Such a rule would apply when the net social costs of exercising the entitlement exceed the private value to the original entitlement holder. Calabresi \& Melamed, supra note , at 1157.

${ }^{13}$ Id. at 1109. 
However, liability rules also have significant drawbacks. While they are less likely to block efficient transactions, they may also permit inefficient entitlement transfers. Liability turns on public, not private, valuation of entitlements. Private parties' valuations of their rights are presumptively accurate, and valuations by judges are bound to deviate from them. This will be especially true for entitlements thatlack objective market values. Liability rules are unlikely to capture highly personalized or idiosyncratic values of things like family heirlooms.Moreover, error a side, public valuation carries with it the costs of litigation - discovery, trial, and so forth. Both the administrative and error costs of liability rules can be seen as types of "transaction costs." Thus, the difference between liability and property is not the existence of transaction costs but whether they are public or private, and whether they arise before the transfer of the entitlement (and can thus prevent the transfer) or after.

Despite the problems in valuing entitlements that are not traded in thick markets, liability rules are often used to protect hard-to-value entitlements like life and bodily integrity. This is because the choice between the property and liability protection requires a comparison of their net costsand benefits When the sum of administrative and error costs (public transaction costs) exceeds those of private bargaining (private transaction costs), property rules will be better than liability rules. Thus, liability rules may be far from perfect in assigning a value to the entitlement destroyed by careless driver who kills someone. But the use of property rules to protect this entitlement would have even higher costs - perhaps the elimination of driving — and thus, the law resorts to liability rules despite their imperfections. ${ }^{14}$

\footnotetext{
${ }^{14}$ Id. at $1108-09$.
} 
Transaction costs can take many forms. The Cathedral focused on holdout problems. Consider the case of a town that, to build an airport, needs to buy one hundred adjacent residential lots, each owned by a different person. Under a property rule, the town needs to strike a deal with the owner of every lot. This gives every owner the power to frustrate the entire project: if just one lot owner holds out, successful deals with the other ninety-nine would accomplish nothing, because there would be a house in the middle of the runway. This veto power allows every owner to holdout for more favorable terms. Such actions could at worst prevent an efficient bargain from ever being reached. ${ }^{15}$ There are also other sources of transaction costs, such as shortness of time and a lack of information on the part of the prospective buyer.

\section{3) Unified framework of analysis.}

The Cathedral shows that the best way of enforcing a legal right cannot be deduced solely from the nature or content of the right itself; instead, it depends on the transaction-cost setting. Personal property, for example, is normally protected by property rules: someone who wants to take another's property must obtain the original owner's consent to do so. But when the same property is destroyed in an accident, it is protected only by liability rule. Similarly, one cannot sell one's life because it is protected by an inalienability rule; however, if someone dies in a car accident, the same entitlement

\footnotetext{
${ }^{15}$ See id. at 1106-07. The free-rider problem, also discussed in The Cathedral, is the buyer-side version of the holdout problem, whereby numerous prospective buyers cannot pool their resources to affect an efficient taking because they cannot require contributions from group members. Government is of course a solution to the freeloader problem. As this Article deals with entitlement takings by the government, only the holdout problem will be relevant.
} 
receives only liability rule protection. Remedial rulesare not determined by the nature or source of the entitlement but by the transaction costs of transferring it. $^{16}$

The Cathedral created a unified framework for the common law categories of tort and property, subjects that had previously been treated as fundamentally distinct. ${ }^{17}$ These common law categories were not about recognizing different types of entitlements, but rather about assigning different types of protection to entitlements based on differences in transaction costs across different settings. "Tort" is a shorthand for the class of situations where transaction costs make negotiations prohibitively costly and "property" for situations where low transaction costs allow for efficient dealings through private negotiation. The Cathedral thus opened the way for pragmatic decision-making about remedial rules, decision-making based on the magnitude of transaction costs.

\section{B. Pliability Rules.}

The Cathedral looks at the assignment of remedies to entitlements at a fixed moment in time. In this static setting, each entitlement is married to a particular type of protection - either property, liability, or inalienability. As a result, commentators often think each entitlement can only be protected by one of the remedial rules. Pliability rules add a dynamic element. They allow a given entitlement to be protected by liability rules in some situations, and property rules in others. The shift from one protection to another can be triggered by the occurrence of a particular situation, by the passage of given period of time, or any other condition one could conceive of. Pliability rules allow for

\footnotetext{
${ }^{16}$ Of course the nature of the entitlement will often affect the size of the transaction costs. Entitlements in non-market goods will be more difficult for courts to value, so all things being equal, such entitlements would be good candidates for property rule protection.

${ }^{17}$ See id. at 1089 (stating goal of providing "unified perspective" on Property and Torts).
} 
great flexibility: the switch from one protection to another can be temporary or permanent; it can even be temporary as against some potential entitlement-takers and permanent against others, and so forth.

This allows the protective regime to change in response to changes in the transaction cost setting. For example, if transaction costs are usually low, property rules will be the best option most of the time. But property rules should not be the permanent protection for the entitlement if one can identify the situations in which transaction costs will rise to the point that the property rule becomes a barrier to efficient transfers. Thus pliability is a more finely-calibrated remedial system than either property or liability rules. The challenge in creating a pliability rule is identifying in advance discrete situations where the transaction costs of taking an entitlement change significantly.

A pliability rule does not merely combine property and liability like gin and tonic. It contains something that its constituent parts do not - a definition of where each part starts and ends. This specification of the "triggering mechanism" represents the valueadded of the pliability rule. ${ }^{18}$ It directs attention to identifying and describing the kinds of circumstances that would make a rule-switch beneficial.

While pliability rules have not received scholarly attention they are often encountered in private law, as Bell and Parchomovsky have shown. Pliability is not a fanciful theory, but rather a richer description of how entitlements are in fact protected. Minority rights in mergers are a common example. ${ }^{19}$ Under normal circumstances, property rules protect shareholders' entitlement to the rights in their shares. These rights

\footnotetext{
${ }^{18}$ See Bell \& Parchomovsky, supra note _, at 31-32 ("[P]liability rules, by defining the triggering event that alters protection from property to liability rule, retains the advantages of baseline property rule protection, while creating the flexibility to adapt to changing circumstances.").

${ }^{19}$ See id. at 32-34.
} 
trade in thick, well-organized markets (created by the requirement that the entitlement be taken at a negotiated price). With low transaction costs, property rules are preferable to liability rules. However, in the event of a merger, the majority shareholders can forcibly take the minority shareholder's rights at a judicially-determined price. The appraisal system creates a pliability rule that switches from a property rule default to a liability rule upon the occurrence of certain types of corporate control transactions, like mergers. The liability "phase" is a one-shot deal; after the forced taking of the minority shares, the protection afforded to the new owners switches back to property rules. But a new corporate control transaction could again temporarily toggle the remedial rule.

\section{Is Constitutional Law Outside The Cathedral?}

Despite the vast influence of The Cathedral, its call for a unified theoretical framework for assigning remedial rules has been largely ignored in constitutional law. ${ }^{20}$ Most commentators reject out of hand the possibility of liability rule protection for constitutional entitlement. ${ }^{21}$ The injunctive essentialist position can be sympathetically

\footnotetext{
${ }^{20}$ See Merrill, supra note _, at 1148 (observing that C\&M framework usually applied to common law entitlements and not constitutional entitlements); Strauss, supra nte_, at $1206-07$ (noting novelty of the idea that C\&M framework can be applied to constitutional entitlements).

${ }^{21}$ See AKHIL ReEd Amar, The Constitution AND CRIMINAL Procedure: FIRST PRINCIPLES 115 \& n.112 (1997) (describing view that constitutional rights should not be transformed into "takings-clause-like "liability" rights" because it would allow the government to "cynically treat violations of sacred constitutional rights merely as the cost of doing business"). See, e.g., David Luban, The Warren Court and the Concept of a Right, 34 HARV. CR.-CL. L. REV. 7, 19-20 \& n.36 (1999) (arguing the "only conceivable notion of constitutional rights" entails "prophylactic protection from potential infringements," and that the Warren Court subscribed to such a property-rule view of constitutional rights); Erik G. Luna, The Models of Criminal Procedure, 2 BUFF. CRIM. L. R. 389, 436 (1999) (arguing that because the emotional injury caused by interference with the home or body are incommensurable, Fourth Amendment doctrine should seek to prevent unconstitutional conduct rather than compensate it, so that the government cannot “"purchase' supposedly inalienable constitutional rights through the expediency of a liability rule.").
}

If rights entail or secure liberties, then it is hard to see how liability rules protect them. . . . Because liability rules neither confer nor respect a domain of lawful control ... [t]he very idea of a 'liability rule entitlement,' that is of a right secured by a liability rule, is inconceivable. 
understood as an overgeneralization of a commonly true proposition: Property rules make more sense than liability rules in most constitutional contexts. Transaction costs are quite low in most situations where governmental interests collide with constitutional entitlements. The government can often obtain consent to a search just by asking, and the costs of doing so without invading constitutional rights are also low. In law enforcement, unless the government or public insists on an unrealistic $100 \%$ crime clearance rate, the holdout power of the rights holder will not be a particular problem.

Much of opposition to C\&M analysis in constitutional law results from ignoring the possibilities of pliability rules. If the only remedial options for constitutional entitlements were property and liability rules, and if the protective rule could never change, than property rules would certainly be the best choice. However, if liability rules would work better in rare but reoccurring situations that can be described in advance, a pliability rule that toggles from property to liability in such situations would be superior to either of the pure rules.

The present subpart shows that there is nothing inherent about constitutional entitlements that would prevent them from being subject to liability rules under the

Jules L. Coleman \& Judy Kraus, Rethinking the Theory of Legal Rights, 95 YALE L.J. 1335, 133940 (1986).

Damages [as opposed to an exclusionary rule for unlawful searches and seizures] would be a kind of forced exchange, and however appropriate that may be in a commercial context where all things are in principle exchangeable, it would be incompatible with the idea of a right specifically against the government, and with the reasons why such rights exist.

James Boyd White, Forgotten Points in the 'Exclusionary Rule' Debate, 81 Mich. L. REV. 1273, 1278 n.21 (1983). Walter F. Dellinger, Of Rights and Remedies: The Constitution as a Sword, 85 HARV. L. REv. 1532,1563 (1972) (arguing that while liability protection might be appropriate for private law rights, "it is inconsistent with a constitutional system"). See also, Richard H. Seamon, The Asymmetry of State Sovereign Immunity, 76 WASH. L. REV. 1067, 1135 n.325 (2001) (observing that constitutional rights are presumptively protected by property rules and thus, more robust than Takings Clause rights). 
circumstances suggested by The Cathedral, ${ }^{22}$ rare as those circumstances may be. It also responds to some serious arguments to the contrary. Of course, even if it would be wise to assign constitutional remedies based on the C\&M criteria, this would be impossible if the Constitution itself mandates property rule protection for individual entitlements. Part IV will show the compatibility of liability rules with the Constitution itself.

\section{1) Incommensurability.}

Perhaps the strongest justification for exclusively using property rules for constitutional rights is that these rights generally protect non-monetary interests that do not lend themselves to objective measurements of compensation. ${ }^{23}$ (When the Constitution creates a right with a market value that isrelatively easy to ascertain — the right to one's property — it explicitly protects it through a liability rule, in the form of the Just Compensation clause.) Valuing most constitutional rights will be difficult for courts,

\footnotetext{
${ }^{22} \mathrm{~A}$ few scholars have, in passing, recognized that what makes liability rules desirable in certain private law contexts might recommend them as remedies for certain constitutional rights. See Bhagwat, supra note _, at $1011 \mathrm{n} .212$ ("There is no obvious reason not to extend [ Takings] approach to other rights, under limited circumstances. It would seem that 'hard cases,' where an individual-rights claimant stands in the way of a large public benefit (or threatens to create a large public harm), present precisely the types of significant transaction costs due to hold-out problems, for which Calabresi and Melamed feel a liability rule is in order."); Merrill, supra note _, at 1157-65 (discussing constitutional rights in a modified C\&M framework and arguing that liability rule may be appropriate for protecting tobacco companies' commercial speech rights). See also, DAVID P. CURRIE, THE CONSTITUTION IN CONGRESS: THE FEDERALIST PERIOD, 1789-1801, 293-94 n.99 (1997) [hereinafter CURRIE, CONGRESS] (observing that while the Takings Clause only applies "explicitly" to property, it could also serve as a "model" for compensation for takings of liberty such as the Japanese interment).

${ }^{23}$ See Merrill, supra note _, at 1163; Vicki C. Jackson, The Supreme Court, the Eleventh Amendment, and State Sovereign Immunity, 98 YALE L.J. 1, 93 (1988) (arguing that constitutional rights should be protected with property rules rather than liability rules "because dignitary relationships between citizen and government" cannot be monetized and attempts to do so would, from the expressive perspective, devalue important political rights).
} 
resulting in high administrative costs. Courts will often be unable to monetize certain dimensions of the entitlement, resulting in undercompensation, a type of error cost. ${ }^{24}$

Most constitutional rights do not have obvious market analogs, making objective judicial valuation difficult. Furthermore, many constitutional entitlements protect a range of nebulous interests, and it can even be hard to even understand which interest is compromised by the taking of the entitlement. For example, while the market value of Fourth Amendment search rights can be sought in such things as the rental value of the premises for the period of the search, this still does not capture an important aspect of the protected interest. The Fourth Amendment does not protect against unlawful entry by private citizens: it protects against unlawful entry by the government. That might be a more serious harm, and one which cannot be priced by the market. Put differently, the price of opening one's doors might turn on who is entering one's house. A landlord may charge an ill-tempered tenant a higher rent, and the government may be seen by a large number of citizens as a particularly undesirable occupant of their homes.

These arguments can easily be understood in C\&M terms. The incommensurability argument is just another way of saying that public transaction costs are high because of the difficulty of objectively valuing the entitlements. Thus, the incommensurability position does not deny that property rule protection might block some valuable rights transfers. It merely maintains that the social loss from transfers left unconsummated because of transaction costs will be lower than the error and administrative costs attendant to a judicial valuation of the constitutional entitlement.

\footnotetext{
${ }^{24}$ See Bernard P. Dauenhauer \& Michael L. Wells, Corrective Justice and Constitutional Torts, 35 Ga. L. Rev. 903, 926 (2001) (observing that some "losses" of constitutional rights, such as the right to hold political demonstrations, "cannot be fully restored" because of the inability to assign a "precise dollar value" to such losses).
} 
Seen this way, the incommensurability argument loses its existential character. It would not be inconsistent with this position to suggest that in certain discrete situations, the balance of costs tilts the other way and the total losses from not allowing the rights-taking would exceed the admittedly high administrative and error costs of liability rules. For example, the Takings Clause is often described as a proper liability rule because there are market proxies for the value of the condemned property. But it is one thing to say that real property "can" be monetized, it is another to say that such monetization will always be fully compensatory. Courts routinely monetize real property, but in the process they fail to incorporate the sentimental value of a family home. Such liability-rule errors are acceptable when their cost is lower than the social benefit from the transfer of the rights. Arriving at some approximation of just compensation is not, however, a futile enterprise. Tort law does not afford prospective relief against careless drivers even though they imperil the most non-pecuniary of interests, life itself. This is because while ex post damages for loss of life are not ideal, the social costs of allowing drivers to enjoin each other would be even greater. Damages are routinely paid retrospectively for unconstitutional detentions and for takings of countless other non-monetary entitlements. The presumptive availability of injunctive relief merely reflects a judgment that ex post damages will tend to undercompensate. To put it in old fashioned terms, equity steps in because legal remedies are inadequate.

Under-compensation is a practical problem, not a philosophical one. It can be mitigated, in principle, by a generous compensation scheme that could include as a separate item the "intangible" aspect of the constitutional right. This should be no harder or easier to quantify than such imponderables as emotional distress, which courts 
routinely monetize. ${ }^{25}$ The under-compensation problem further diminishes if one accepts the contention of this Article that pliability rules would on the whole result in relief where it would not be forthcoming under pure property protection. Undercompensation is bad, but better than forfeiture. To be sure, this does not entirely solve the problem because constitutional rights are individual. A particular detainee might concede that the net effect of pliability rule is greater relief for detainees as a class, but argue that in his particular case, it results in less protection than he would enjoy under a property rule. ${ }^{26}$

\section{2) Resentment costs.}

Another objection to constitutional liability rules is that forced takings of constitutional entitlements may have particularly high net "resentment costs." This is the additional psychological or dignitary cost of having an entitlement forcibly taken. Such costs are not unique to coercive takings of constitutional entitlements: indeed, they were recognized by The Cathedral. ${ }^{27}$ In the common law context, C\&M argued that resentment costs exist regardless of the remedial rule. Those who wish to purchase an entitlement for its market value but cannot do so "because the market is unable to pay off those who are holding out for a greater than actual value" will also resent their inability to

\footnotetext{
${ }^{25}$ See id. at 927 ("Courts have rejected th[e] argument [that nonpecuniary injuries cannot be compensated with damages] in the common law context, and should do so in the constitutional tort context as well. . . Courts have defended damages for pain and suffering in ordinary tort law as a reasonable way to make the best of a bad situation.").

${ }^{26}$ The Court may be sympathetic to such arguments. For example, it upheld the Japanese detentions, clearly believing that the harm to the Japanese was outweighed by substantial national interests. However, in a separate case, it ordered the release of person who the Executive conceded to be totally loyal, on the grounds that Congress had not authorized the detention of people whose loyalty had been affirmatively established. Ex parte Endo, 323 U.S. 283, 285, 300-02 (1944).

${ }^{27}$ Calabresi \& Melamed, supra note , at 1108 n.36.
} 
impose an objectively efficient solution. As C\&M put it, "unascertainable resentment cost may exist as a result of either coercion or market failure."

The dominance of property rules in the constitutional context reflects, in part, a judgment that resentment costs cut clearly against liability rules when the government is the coercer. The psychological or political origins of this assumption are beyond the scope of this Article, but it is likely rooted in a fear of governmental power, a suspicion of governmental motives, and a feeling of helplessness in the face of the biggest bully in town. However, one can see it the other way: it might be more offensive to be coerced by an equal than a superior power. Thus, high resentment costs only tell part of the story.

One must consider net resentment costs — the difference between the resentment felt by a coerced entitlement holder under a liability rule and a frustrated efficient purchaser under a property rule. The government cannot "resent," but the society it represents can. However, this society will largely be ignorant of and indifferent to most holdouts, and the cost of the resentment will be widely diffused. But C\&M's admonition to look at both sides of the resentment cost balance hints that in some situations, resentment costs could tilt in favor of liability rules even in the constitutional context. For example, the Fourth Amendment's exclusionary rule, a property right protection, has generated considerable public outrage. Not coincidentally, the Fourth Amendment has occasioned some of the rare proposals that constitutional violations be remedied by damages instead of specific relief. ${ }^{28}$

\footnotetext{
${ }^{28}$ See Jackson, supra note __, at 93.
} 


\section{3) Government as imperfect agent.}

David Strauss has argued that the C\&M framework should not apply to constitutional rights on the grounds that the government, unlike private actors in common law, does not internalize the full cost of its actions. Thus, under a liability rule it might "condemn" individual rights even when this results in a net social loss. ${ }^{29}$ Constitutional liability rules make sense when there are net social benefits to a taking of the entitlement, but these benefits cannot be realized due to transaction costs. "Society," however, cannot take these rights; the government must do so, acting in society's name. The government is, as Strauss notes, often an imperfect agent for society. Under liability rules, the government might condemn rights out of sinister motives.

Strauss's objection is serious, but it proves too much in two ways. First, many private actors, such as large publicly-traded corporations, are imperfect agents. This does not make the C\&M property/liability framework inapplicable to them. Rather, entitlements are still assigned based on transaction costs, and the agency problem is policed through a mixture of political measures (shareholder voting) and judicial oversight (the appraisal remedy and actions for breach of fiduciary duty). In other words, the presence of agency costs is not generally seen as something to be addressed through the choice of remedial regime.

Second, the government is an imperfect agent whatever it does. Its motives are thus, always suspect. Strauss does not show or suggest that liability rules for constitutional rights would increase the principal-agency slippage inherent in government. Yet the law has political and judicial ways of policing this agent problem.

\footnotetext{
${ }^{29}$ Strauss, supra note _, at 1208-09.
} 
For example, the Takings Clause, which explicitly creates a liability rule for condemnation of property, has a "public use" requirement. ${ }^{30}$ Usually the government does not need to prove anything about its motives when it acts; a prosecutor need not affirmatively demonstrate that he uses his discretion for the common good. In the takings context, with its shift to liability rules, a proper governmental purpose must be shown to a court. This implicitly recognizes that the payment of damages itself will not be enough to ensure efficient government action under a liability rule. By analogy to the Takings Clause, a "public use" type inquiry into governmental motives would be an integral part of any other constitutional liability rule.

\section{Pliability Rules for Mass Detentions}

The case for liability rules can only be made in comparison to the consequences of property rule protection. So Part II.A describes how the Supreme Court, operating under a property rule-only paradigm, has responded to mass detentions. This subpart shows that the property rule has done little to protect constitutional rights, as the Court has repeatedly stood aside during mass detentions. The Court's unwillingness to stop mass detentions obviously leaves the innocent detainees without any protection for their constitutional rights. It also works mischief to constitutional doctrine, because the Court

\footnotetext{
${ }^{30}$ To put it more precisely, Takings jurisprudence once had a public use requirement. The Supreme Court has in effect eliminated it, holding it to be "coterminous with the scope of a sovereign's police powers," so that any purported purpose would suffice. Hawaii Housing Auth. v. Midkiff, 467 U.S. 229, 240-41 (1984) ("Where the exercise of the eminent domain power is rationally related to a conceivable public purpose, the Court has never held a compensated taking to be proscribed by the Public Use Clause.") (emphasis added). In Midkiff, the Court unanimously upheld the use of the takings power to transfer land from one group of private landowners to another, with the asserted "public use" being the breaking-up of large concentrated land holdings. Id. at 241-42. See also, Levinson, Making Government Pay, supra note _, at 365 n.63 ("As a matter of constitutional doctrine, the public use limitation has been long dead.").
} 
can only avoid freeing the detainees by cutting back on the substantive law that would protect them. Part II.B explains how this unhappy state of affairs is caused by the property rule itself, and can only be cured the introduction of a remedial alternative. Mass detention situations are characterized by extraordinarily high transaction costs that could prevent socially optimal measures from being taken under the property rule protection that obtains in tranquil times. Because the Court is unwilling to impose the social costs of the property rule, it cannot find the detentions unconstitutional in the first place.

Having shown the problems of property rule protection as a matter of practice (Part II.A.) and theory (Part II.B.), this Part introduces the pliability rule -- an alternative remedial structure that would greatly reduce these problems. Part II.C suggests that the constitutional entitlement to liberty should be protected by a pliability rule under which the government would in effect be allowed to make compensated "takings" of liberty in certain narrow circumstances — in particular, mass detentions in security emergencies.

Some caveats are in order. This Article makes no assumptions about whether the specific mass detentions discussed herein were justified as a matter of law or policy. Instead, it merely recognizes that in national security emergencies, both individual liberty and public safety are imperiled. Both security and liberty as good things, and this Article does not hope to define the optimal trade-offs between them. The argument of this Article would still be valid if mass detentions were never a socially efficient strategy (in the Caldor-Hicks sense that the harm suffered by detainees is lower than the harm the detentions would succeed in preventing. $)^{31}$ Even under that restrictive assumption, the

\footnotetext{
${ }^{31}$ What is important for the analysis is that courts believe that detentions can prevent enemy action, or are at least willing to defer to the executive's judgment in this regard. The existence and likely persistence of such beliefs and deference are documented in Part II.A. It is this deference that deters courts from holding suspicionless detentions in national security emergencies to be unconstitutional.
} 
temporary substitution of money damages for injunctive relief would be an improvement on the reigning injunctive essentialist paradigm, which has the perverse consequence of leaving detainees entirely uncompensated. However, this Article's proposal would be even more valuable if, as is more realistic, detentions can yield some security benefits.

\section{A. Judicial Tolerance of Mass Detentions.}

Constitutional liberty rights are nominally protected by property rules at all times. In reality, during national security emergencies these entitlements receive an ad hoc hodge-podge of property rule protection, a grossly undercompensatory version of liability protection, and most often no protection at all. Thus, subpart shows that the Supreme Court responds to mass detentions in one of two ways: deference and delay. It may sustain the measure, holding that a pressing social need trumps the individual entitlements at stake. Or it may duck the constitutional question, at least until after the crisis subsides. These expedients, which have significant drawbacks, are the unsurprising consequences of being stuck with a property rule in high transaction cost situations.

\section{1) Deference.}

The Court tends to uphold arguably unconstitutional detentions during national emergency in deference to Executive affirmations of the detentions' importance. In the Civil War, President Lincoln suspended habeas corpus, allowing the Secretary of War detained 13,000 Northern civilians, most of them political opponents of the war. The arrests were either made without charges, or under vaguely defined offenses created by 
executive decrees. ${ }^{32}$ During World War II, approximately 120,000 Japanese were

interned in camps on the basis of military orders. ${ }^{33}$ The government detained some 1,200

people within two months of the September 11 attacks, often holding them for months

without filing charges. ${ }^{34}$ In none of these episodes did the courts invalidate the mass

detentions. (This is not to suggest that the three sets of detentions are comparable on their

merits, but only to observe that as an empirical matter the judiciary has never stood in the

way of such measures in times of armed conflict.) Thus, in practice, the liberty

entitlement received police power protection, which is to say, none at all.

Of course, the judicial response to these mass detentions -- the Japanese episode

in particular -- has been widely criticized. Congress has apologized for the Japanese

detentions $^{35}$ and paid compensation ${ }^{36}$ (in effect adopting a liability rule, though the small

\footnotetext{
${ }^{32}$ William H. RehNQuist, All the Laws But One: Civil Liberties in WARtime 49-50, 60 (1998). Most of the detainees were Northern Democrats from border states who opposed the war against the Confederacy and may even have wished their state to secede, or criticized conscription and emancipation. See JAMES M. MCPHERSON, BATTLE CRY OF FREEDOM: THE CIVIL WAR ERA 493-94 (1988). The precise number of detainees is a matter of some controversy, and cannot be easily reconstructed from the fragmentary records. Estimates range from a few thousand to 38,000. See MARK E. NEELY, JR., THE FATE OF LiBERTY: ABRAHAM LINCOLN AND CIVIL LIBERTIES 114-138 (1991) (reviewing historical evidence on number of arrests, and concluding that higher estimates more likely correct, but that more than half of the arrestees were citizens of Confederate states).

${ }^{33}$ See Commission on Wartime Relocation and Internment of Civilians Act, Pub. L. 96-317, § 2(a)(1), 94 Stat 964 (1981) (finding that "approximately one hundred and twenty thousand civilians were relocated and detained in internment camps pursuant to Executive Order Numbered 9066, issued February 19, 1942").

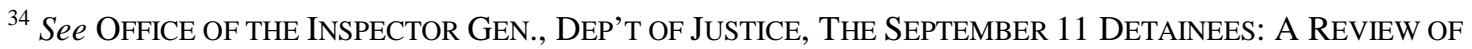
THE TREATMENT OF ALIENS HELD ON IMMIGRATION CHARGES IN CONNECTION WITH THE INVESTIGATION OF THE SEPTEMBER 11 ATTACKS 1 (2003) [hereinafter THE SEPTEMBER 11 DETAINEES]. Approximately 762 detainees were aliens, most of whom were ultimately charged with violations of immigration laws. Id. at 2 . The Federal Bureau of Investigation adopted a policy under which the detainees would be "held until cleared" of involvement in terrorism, with no bond available. Id. at 37 . The average alien detainee was held for 80 days awaiting such clearance. Id. at 196. A smaller number of people were held without charges under the material witness statute, 18 U.S.C. $\S 3144$ (2003). Only a few of the 1,200 detainees have been convicted of terrorism-related offenses.

${ }^{35}$ See Pub. L. 100-383, § 1989(a), 102 Stat. 903 (1988) (“Congress recognizes that ... a grave injustice was done to both citizens and permanent resident aliens of Japanese ancestry by the evacuation, relocation, and internment of civilians during World War II."); § 1989(2) (issuing "apolog[y] on behalf of the people of the United States for the evacuation, relocation, and internment" of Japanese during the war).
} 
amount and forty-five year delay makes it more symbolic than truly compensatory, for the amount would not even cover interest on damages if assessed at the time of the violation). One might think that an increased solicitude for constitutional rights and the expansion of the actual scope of those rights, and an embarrassed awareness of the mistakes of the past will reduce the likelihood of such judicial quietude in the face of future detentions. Yet interwar remorse and the progress of liberties will most likely have no effect on judicial behavior in the next crisis. Chief Justice Rehnquist has written that volumes of commentary on the proper role of the judiciary in such crises are "largely academic," because "there is no reason to think that future Justices of the Supreme Court will decide [similar] questions differently from their predecessors." ${ }^{37}$ Even scholars who take a much less forgiving view of the Japanese internment cases than does the Chief Justice recognize that they would be repeated again in similar circumstances. ${ }^{38}$

Indeed, if there was ever a time to predict that courts would not easily defer to the executive in such situations, it would have been in the late 1980s and 1990s, after the

\footnotetext{
${ }^{36}$ See $§ 1989$ (4) (authorizing payment of \$20,000 to Japanese detainees). In all, 82,219 people received compensation (many of them next-of-kin to deceased detainees), and twenty-eight refused to accept the money. See Mitchell T. MAKi et AL., ACHIEVING the Impossible Dream 23 (1999).

${ }^{37}$ See McPherson, supra note _, at 224.

38 The history of our nation's response to threats and attacks does not support this belief [that the courts will "rein in" governmental intrusions on civil liberties in the wake of September 11.] Time after time, the courts, lawyers, and bar associations -- no different from the majority of other Americans -- gave their stamp of approval to these infringements, done largely in the name of national security.

Nancy Murray \& Sarah Wunsch, Civil Liberties in Times of Crisis: Lessons From History, MASs. L. REV. (2002). See, e.g., Alfred C. Yen, Praising With Faint Damnation - The Troubling Rehabilitation of Korematsu, 40 B.C. L. REV. 1, 2 (1998) (arguing that Court's failure to overturn Korematsu "heightens the chance that out country will someday intern innocent civilians once again"); Joel B. Grossman, The Japanese American Cases and the Vagaries of Constitutional Adjudication in Wartime: An Institutional Perspective, 19 U. HAW. L. REV. 649, 650-51 (1997) (suggesting that in the future the Court will be no more able than in the past to "withstand the enormous pressures to support, or at least defer to, the government, that inevitably accompany a wartime crisis").
} 
public atonement for the Japanese interment and the coram nobis cases. ${ }^{39}$ Yet in the few cases arising from the very recent detentions of Moslems and Arabs, the courts generally accepted the Administration's position that the measures were warranted by national security concerns. ${ }^{40}$ The Supreme Court has not ruled on any of these measures. But it has signaled its probable attitude. A few months before the September 11 attacks, the Court hinted in dicta that terrorism might be a "special circumstance" that calls for "forms of preventive detention and for heightened [judicial] deference to the judgments of the political branches with respect to matters of national security." ${ }^{41}$ It is difficult to imagine this view softening after a terror attack of previously unimaginable magnitude. Institutional and psychological reasons make judges reluctant to strike down such measures. The deep-rooted causes of judicial reluctance suggest the phenomenon will persist in future emergencies. Jurisprudential strategies intended to advance civil liberties in times of crisis should take this judicial tendency as an empirical fact and work around

\footnotetext{
${ }^{39}$ See Hirabayashi v. United States, 828 F.2d 591, 608 (9th Cir. 1987) (vacating petitioner's wartime exclusion and curfew convictions through writ of error coram nobis on grounds that the orders had been motivated by racial prejudice rather than military necessity for orders); Korematsu v. United States, 584 F. Supp. 1406, 1420 (N.D. Cal. 1984) (granting writ of coram nobis vacating wartime conviction for violation of exclusion order).

${ }^{40}$ See North Jersey Media Group, Inc. v. Ashcroft, 308 F.3d 198, 219-220 (3rd Cir. 2002) (Becker, C.J.) (upholding constitutionality of closed deportation hearings on national security grounds).

The need for deference in this case is just as strong as in earlier cases. America faces an enemy just as real as its former Cold War foes, with capabilities beyond the capacity of the judiciary to explore. . . The judiciary is in an extremely poor position to second-guess the executive's judgment in this area of national security. We therefore reject any attempt to artificially limit the long- recognized deference to the executive on national security issues.

Center for National Security Studies v. Department of Justice, 331 F.3d 918, 928 (D.C. Cir. 2003) (rejecting FOIA request for names of post-September 11 immigration detainees). Cf. Detroit Free Press v. Ashcroft, 303 F.3d 681 (6th Cir. 2002) (finding First Amendment right of access to immigration proceedings not trumped by proffered national security considerations, and thus, authorizing injunction because "even a minimal infringement upon First Amendment rights constitutes irreparable injury sufficient to justify injunctive relief').

${ }^{41}$ Zadvydas v. Davis. 533 U.S. 678, 696 (2001).
} 
it, rather than devising solutions that sound attractive in principle but will be unlikely to be implemented in practice.

Doctrinally, judicial silence during mass detentions is facilitated by the deference courts pay to the executive in national security matters. ${ }^{42}$ The sources of this deference are both constitutional and pragmatic. Judges lack the training or resources to intelligently evaluate the factual bases for national security determinations. Judges see security arrangements as principally a matter for the Executive, ${ }^{43}$ a view bolstered by the Constitution's commitment of the Commander-in-Chief role to the President and the Take Care clause. Of course the courts insist that constitutional questions remain the special province of the courts, but the separation of powers concerns will make them reluctant to reach a constitutional decision that would in practice impede the executive's power over security matters. Such deference has no obvious logical limits, and that is its

42 Where, as they did here, the conditions call for the exercise of judgment and discretion and for the choice of means by those branches of the Government on which the Constitution has placed the responsibility of warmaking, it is not for any court to sit in review of the wisdom of their action or substitute its judgment for theirs.

Hirabayashi, 320 U.S. at 93. See also, Charles A. Shanor \& L. Lynn Hogue, NATiOnAL SeCURITY AND MILITARY LAW IN A NUTSHELL 24 (2003) ("While there are no apparent textual limits on jurisdiction with respect to national security cases, judicial review has been very restrained with respect to such cases.").

${ }^{43}$ See, e.g., Hirabayashi, 320 U.S. at 93 ("The Constitution commits to the Executive and to Congress the exercise of the war power in all the vicissitudes and conditions of warfare.").

Courts must defer to the executive on decisions of national security. . In undertaking a deferential review we simply recognize the different roles underlying the constitutional separation of powers. It is within the role of the executive to acquire and exercise the expertise of protecting national security. It is not within the role of the courts to secondguess executive judgments made in furtherance of that branch's proper role.

Center for National Security Studies, 331 F.3d at 932.

We are quite hesitant to conduct a judicial inquiry into the credibility of these security concerns, as national security is an area where courts have traditionally extended great deference to Executive expertise... The assessments before us have been made by senior government officials responsible for investigating the events of September 11th and for preventing future attacks... To the extent that the Attorney Generals national security concerns seem credible, we will not lightly second-guess them.

Jersey Media Group, Inc., 308 F.3d at 219. 
great danger, as Justice Jackson noted in his Korematsu dissent. ${ }^{44}$ (It will not do to say that the Constitutional rights are themselves the limits, because most concede that even the clearest right would yield to a grave enough necessity, and if the Court allows the Executive to announce such necessities, there is little work left for it to do.)

As Judge Posner has observed, psychological tendencies also make judges reluctant to second-guess measures like detentions in times of crisis. Judges, perhaps more than most people, value their reputations (with their income fixed, reputation is the principal margin on which judges can improve their utility). Like most people, they are risk averse. If a court decides a case in way that allows for detentions to continue, there may be recriminations from civil libertarians, but the court will probably not receive as much public abuse, because emergency measures are generally quite popular. ${ }^{45}$ On the other hand, if the Court enjoins a mass detention program, a small number of the detainees may in fact go on to inflict great violence to the nation. A court that frees a terrorist who then blows up a building will likely come in for a great deal of abuse, and the judges of course will feel rather guilty. Any possible guilt about allowing detentions to continue could be shared with the executive (this is the psychological role of national security deference), whereas the court that enjoins detentions would feel the full downside of its decision.

\footnotetext{
$44 \quad$ I cannot say, from any evidence before me, that the orders . . . were not reasonably expedient military precautions, nor can I say that they were. But even if they were permissible military procedures, I deny that if follows that they are constitutional. If, as the Court holds, it does follow, then we may as well say that any military order will be constitutional and have done with it.
}

Korematsu, 323 U.S. at 245 (Jackson, J., dissenting).

${ }^{45}$ See Richard A. Posner, Executive Detention in Time of War, 92 MICH. L. REV. 1675, 1681 (1994) (reviewing A.W. BRIAN SIMPSON, IN THE HigheST DEgREE OdiOUS: DETENTION WITHOUT TRIAL IN WARTIME BRITAIN (1992)) (observing that judges "care about their status and are reluctant to check the executive in matters of national security.") 
Furthermore, as members of the polity under attack, judges are not completely impartial in security matters because they may well bear the costs of a compromised security if the detainees are released. In cases like Korematsu, Bhagwat has observed, "judges are ... part of the majority which the Constitution seeks to restrain." ${ }^{46}$ Thus, under a property rule regime, they would be expected to give undue weight to the security imperatives compared to the constitutional ones.

These considerations suggest that judicial reluctance to interfere in mass detentions will not be sensitive to liberalizing changes in constitutional norms. When institutional and psychological tendencies reinforce each other, the effect is hard to shake. So from a positive perspective, the question is not whether future detainees will get damages instead of injunction but whether they will get any timely redress.

\section{2) Delay and abstention.}

The Court often avoids any ruling on the constitutionality of mass detentions, or at best acts only belatedly. ${ }^{47}$ (On the few occasions that the Court has found that the Executive's wartime measures violated civil liberties, it has waited until the crisis has passed to announce its decision. $)^{48}$ In Hirabayashi the Court did not, contrary to the popular impression, sustain the executive internment orders. Rather, it upheld the

\footnotetext{
${ }^{46}$ Bhagwat, supra note ___, at 988.

${ }^{47}$ See REHNQUIST, supra note __, at 221 ("Judicial reluctance [to contradict executive security measures in times of war] can manifest itself in more ways than one. A court may simply avoid deciding an important constitutional question in the midst of a war.").

${ }^{48}$ See, e.g., Ex parte Milligan, 71 U.S. (4 Wall.) 2, 121-23 (1866) (holding that Constitution was violated by military trial of civilian in Indiana for aiding Confederacy); Duncan v. Kahanamoku, 327 U.S. 304, 324 (1946) (holding that trial of civilians in Hawaii by military tribunals was not authorized by statute allowing for martial law). The Court had avoided deciding the issue in Milligan during the war by ruling that it did not have jurisdiction over direct appeals from the military commissions. See Ex parte Vallandigham, 68 U.S. (1 Wall.) 243 (1864).
} 
executive curfew order, but avoided ruling on the legality of the more draconian exclusion order that Gordon Hirabayashi had also violated. The Court said it would not reach the question because the sentence for the latter offense would be served concurrently with the one for violating the former. ${ }^{49}$ However, scholars of the episode conclude that the Court was not merely displaying its customary reluctance to unnecessarily reach constitutional issues, but choosing to duck an important question because the circumstances put a satisfactory answer out of reach. ${ }^{50}$ Uncomfortable with the property rule dilemma, the Court did nothing.

The stall accomplished nothing. Eighteen months later the Court was forced to rule on the exclusion order, and upheld it. ${ }^{51}$ But the notorious Korematsu opinion ducked yet another and more important issue: the legality of the detention orders. ${ }^{52}$ There would be "time enough to decide the serious constitutional issues" at a later date, the Court wrote in the last year of the war, when victory was in sight. ${ }^{53}$ Here the procedural grounds for avoidance were weaker than in Hirabayashi. Fred Korematsu would have to be in "certain" peril of running afoul of the relocation order for the Court to act - a standard far higher than the normal equitable standard of "high likelihood" of a future deprivation of constitutional rights. Certainly the relocation program challenged by Korematsu was not speculative, and on its face applied to him.

\footnotetext{
${ }^{49}$ Hirabayashi, 320 U.S. at 85.

${ }^{50}$ See REHNQUIST, supra note __, at 22 1-222.

${ }^{51}$ Korematsu, 323 U.S. at 219.

${ }^{52}$ Id. at $221-23$.

${ }^{53} I d$. at 222.
} 
The Court's de facto abstention doctrine ${ }^{54}$ enjoys the support of influential commentators ${ }^{55}$ including the current Chief Justice (yet another reason to believe the Court will not be more active in future mass detention cases). They favor such procrastination for two reasons. For one, the Court may feel freer in peace than in war to honestly interpret the Constitution in a way solicitous of liberties. ${ }^{56}$ Premature adjudication could saddle constitutional jurisprudence with a precedent unduly burdensome to civil liberties in peacetime..$^{57}$ On the other hand, a decision championing liberty over security interests could result in a show-down with the Executive that the Court could well lose, injuring its prestige and power. Given such unpalatable options, abstention may be the best compromise, as it at least avoids the precedential effects of a narrow reading of constitutional rights. The approval of abstention in such cases implicitly recognizes that the social costs of applying a property rule will be so high that courts would instead choose to extend no protection. But abstention only seems attractive because courts and commentators have not recognized the possibilities of pliability rules, which allow for compromises more favorable to individual rights.

\footnotetext{
${ }^{54}$ Although national security abstention — or "Vallandigham-Hirabayashi abstention" as it could be called - has not been formally acknowledged by the Court as an abstention doctrine, it has been described as such by commentators and by a member of the Court. See REHNQUIST, supra note _, at 222; Shanor \& Hogue, supra note _, at 25. It is, however, far more severe in its consequences than the textbook abstention doctrines, which generally defer a constitutional decision in favor of proceedings in state or administrative tribunals. In Vallandigham-Hirabayashi abstention, on the other hand, there are no imminent or parallel proceedings that might vindicate the rights in question.

${ }^{55}$ See, e.g., REHNQUIST, supra note _, at 222 (suggesting that it may be "desirable to avoid decision on such claims in time of war"); DAVID P. CURRIE, THE CONSTITUTION IN THE SUPREME COURT: THE SECOND CENTURY, 1888-1986, 284 (1990) [hereinafter CURRIE, SUPREME COURT] (describing as "prudent" Court's decision to announce Duncan ruling only after the war).

${ }^{56}$ See REHNQUIST, supra note _, at 222 (suggesting Duncan would have come out the other way if decided during the war); LAWRENCE TRIBE, AMERICAN CONSTITUTIONAL LAW 181 (1978) (speculating that Milligan would have come out differently if decided during the war.)

${ }^{57}$ See REHNQUIST, supra note __, at 222 (suggesting that "the body of case law might benefit from such abstention.”).
} 


\section{B. Extraordinary Transaction Costs.}

The government faces relatively low transaction costs when it seeks to take an individual's liberty in the standard criminal context, through arrest and prosecution. The government deals with criminal suspects one by one. Because criminal prosecution is retrospective - focused on crimes that have already been committed — shortness of time is a relatively weak constraint. Once charges are filed, the statute of limitations stops running, there is little time pressure on plea bargain negotiations, as demonstrated by the ubiquity of such deals. ${ }^{58}$ Delays to continue developing evidence will most often have negligible negative consequences.

National security emergencies have an entirely different transaction cost structure - characterized by a radical shortage of time and information, a large number of discrete rights-holders, and serious adverse selection problems. Mass detentions are about prevention, not prosecution. ${ }^{59}$ They occur when society faces an imminent threat of massive injury, but the very imminence of the threat leaves the government with no time

\footnotetext{
${ }^{58}$ The Speedy Trial Act requires defendants to be tried within 70 days of their indictment, see 18 U.S.C. $\S$ 3161 (2003), but in practice the government has ample breathing room to develop its case. Judges have broad discretion under the statute to grant the government a continuance where it would serve the "ends of justice." $I d$. at $\S 3161(\mathrm{~h})(8)$. They routinely grant such continuances in multi-defendant and other complex cases. See J. Andrew Read, Comment, Open-Ended Continuances: An End Run Around the Speedy Trial Act, 5 GEO. MASON L. REV. 733, 736 (1997). Furthermore, "courts have displayed a willingness to grant continuances to facilitate ongoing negotiations of a plea agreement." Id. at 737. Most broadly, some courts of appeals grant continuances simply to "allow the government adequate time to prepare for trial" by collecting or analyzing evidence. $I d$. at $736 \&$ n. 30 (citing cases).

${ }^{59}$ See THE SEPTEMBER 11 DETAINEES, supra note _, at 12-13 (citing Attorney General's statements after September 11 that Justice Department's "single objective" was to "prevent terrorist attacks"); Executive Nominations: Hearing Before the Senate Comm. on the Judiciary, 105th Cong. (July 8, 2003) (statment of Michael J. Garcia) (describing mass detentions after September 11th in which he was involved as acting INS commissioner, as an "exercise in disruption").
} 
to conduct individualized investigations. ${ }^{60}$ As one Justice Department official put it during an internal discussion of the September 11 detentions, "we have to hold these people until we find out what is going on." ${ }^{61}$ To put it differently, if the government were to investigate potential detainees one-by-one, the damage that could be done in the interim will dwarf, and indeed moot, the benefits of property rule protection. ${ }^{62}$ Liability rules, on the other hand, allow for an instantaneous transfer of entitlements (with the drawn-out part postponed to the subsequent judicial proceedings).

The adverse selection problem arises from the large number of rights holders, and the uselessness of striking deals with only some of them. The government does not know who the genuine terrorists are, and thus, it facesa large and undifferentiated mass of potential suspects. ${ }^{63}$ If the government announced that it wishes to detain people of a particular national origin or ideological inclination, those who would voluntarily turn

\footnotetext{
${ }^{60}$ See, e.g., REHNQUIST, supra note _, at 205 (emphasizing the "need for prompt action" in the wake of Pearl Harbor as a good reason, if not ultimately a justification, for Japanese interments). The Hirabayashi Court emphasized that the War Department faced a "danger requiring prompt action," given the speed of the Japanese advances in the Pacific, 320 U.S. at 95, and "imminent" threat to the nation, 320 U.S. at 104. Justice Douglas based his concurrence largely on the inability to conduct normal procedures ex ante:
}

$[\mathrm{W}]$ here the peril is great and the time is short, temporary treatment on a group basis may be the only practicable expedient whatever the ultimate percentage of those who are detained for cause. To say that the military in such cases should take the time to weed out the loyal from the others would be to assume that the nation could afford to have them take the time to do it. But as the opinion of the Court makes clear, speed and dispatch may be of the essence. Certainty we cannot say that those charged with the defense of the nation should have procrastinated until investigations and hearings were completed.

Id. at 107 (emphasis added).

${ }^{61}$ See THE SEPTEMBER 11 DetAinEES, supra note 1 , at 38.

${ }^{62}$ See id. at 39 (quoting Justice Department official as saying during internal discussion of September 11 detentions, that "if we turn one person loose we shouldn't have, there could be catastrophic consequences").

${ }^{63}$ A detailed description of the these transaction costs can be found in the Justice Department Inspector General's report, THE SEPTEMBER 11 DETAINEES, supra note 1, at 52-66. It took the government much longer to screen alien detainees under the "hold until cleared" policy than officials had planned. The delays were caused by the administrative difficulties of quickly investigating the large number of detainees, as well as the disruption of FBI operations caused by the attacks themselves. 
themselves in would be the innocents, not the enemies planning an attack. ${ }^{64}$ (To put it differently, the enemies place an extraordinarily high value on their liberty, and thus, a price that would convince innocents to transfer their entitlement will not induce the guilty.) ${ }^{65}$ Thus, the situation resembles one where the government wishes to build public works on land owned by many people; unless it can take all owners' entitlements in one transaction, the project will be mortally threatened by holdouts. It is important to note that the property rule equilibrium would have all the drawbacks of a liability rule namely, the detention of all the innocents in exchange for compensation - without its principal advantage of pulling in the guilty.

Another way of understanding the heightened transaction costs is to focus on the large magnitude of the damage the actual enemy agents hope to inflict. In the criminal context, one can assume murder suspects are fairly fungible. That is, there are a large number of them, and each poses a roughly equal threat to society. Thus, the prosecutor can pursue cases (either by proving the guilt of or by striking plea deals) starting with the easiest to the hardest; whatever portion of the total suspects that go free, they are no more dangerous than those successfully incarcerated. As a result, criminal suspects lack monopoly power. Among a class of potential detainees, on the other hand, there is no fungibility. The great majority of detainees will be innocent and harmless, but a small minority will pose an extraordinary threat, far greater than that posed by the average

\footnotetext{
${ }^{64}$ Merrill makes this point in support of liability rules for searches of property under the Fourth Amendment: "the owners of the properties the government is most anxious to search would have a monopoly power that would raise transaction cost barriers to negotiation." Merrill, supra note , at 1164 .

${ }^{65}$ An intriguing strategy would be to use the adverse selection phenomenon to identify terrorists, or at least narrow down the list of detainees. The government could offer generous payments to potential detainees who turn themselves in - but then arrest only those who do not agree to such a transaction, on the grounds that these hold-outs are more likely to be those who pose the threat. What makes this strategy far-fetched -like most acoustic separations schemes -- is that it would have to be completely secret, for otherwise the enemy agents would offer to turn themselves in, defeating the scheme's information-revealing power.
} 
criminal. If the dangerous ones are not swept in, the detentions serve no purpose; and it is precisely the dangerous ones that would not be detained under a property rule. To put it differently, property rules work well on the retail level, but will be undone by holdout and adverse selection problems if applied on a wholesale level.

Resentment costs may cut against forced takings by the government in most circumstances. The private resentment costs under a liability rule are obvious, while there may be no public resentment under a property rule that prevents a socially efficient rights-taking for the simple reason that the public would never be aware of the blocked transaction. However, in the context of a national security emergency public and private resentment costs are much more closely balanced. Resentment costs increase with the size of the benefits foregone as a result of property rules in a high transaction cost environment. Mass detentions not only foster resentment among those deprived of their liberty, they also alienate their entire social group, potentially for a long time. But there would also be enormous public resentment if an enemy attack were not foiled because mass detentions are unfeasible under a property rule.

\section{Introducing the Mass Detention Pliability Rule.}

In the initial, default phase of the pliability rule, the liberty entitlement receives property rule protection, as it does under current constitutional doctrine and practice. However, liability rule protection is triggered by a national security emergency — such as a foreign attack on the United States — in which the government presents a credible need for mass detentions. The "trigger" is an essential element of the pliability rule. For the liability rule phase to kick in, a court must first determine that the "triggering event" 
has occurred. In making this judgment, it would look to the presence of the extraordinary transaction costs and competing interests that justify temporary liability rule protection — a shortage of time for individualized investigation, and the need to sweep in a large number of people to accomplish the security goals.

The requirement of a liability-rule triggering event preserves property rules as the dominant protection for constitutional rights. The only possibility for a "slippery slope" into a de facto default liability rule would be the improper judicial application of the triggering criteria. Judges may prove too quick on the "trigger" or unable to call an end to the liability-rule phase when the emergency is over. But the triggering feature of pliability rules does not create any novel problems of judicial administration. The triggering determination is a sort of constitutional triage analogous to the preliminary decision to analyze an alleged constitutional violation under strict scrutiny, intermediate scrutiny, or rational basis review. ${ }^{66}$ The hair-trigger problem could be mitigated through standard legal tools like a narrow and precise statutory definition of the triggering event.

The advantage of the pliability rule is that it gives courts a range of remedial options to respond to a range of possible circumstances. The pliability rule is like a tool belt that keeps the remedial tools of property rules, liability rules, and police power rules all close at hand, easy to reach when called for. Thus, a crucial feature of the pliability rule is that it does not require a switch to liability rules in the face of any mass detention. Property rules will still be available to invalidate mass detentions, as will police power rules to sustain them. This is because liability protection is triggered not just by the occurrence of a mass detention, but only by a mass detention used to prevent attacks

\footnotetext{
${ }^{66}$ See Bhagwat, supra note cases" like Korematsu). , at 963 (discussing the role of the levels of scrutiny in managing "hard
} 
during a national security crisis. If detentions are designed to silence political opponents or abuse a vulnerable minority the liability rule would not be triggered and the detainees would enjoy standard property rule protection. The transaction cost justification for liability rules does not exist in such cases, because the taking is by definition inefficient. Turning to the opposite situation, the government might implement a massdetention program that only arrests those against whom it has actual, individualized evidence. If such detentions satisfy the normal constitutional standards, the "police power" rule would apply — that is, the government could take the detainees' liberty with no compensation, just as it can arrest suspected criminals and jail convicted ones in peacetime.

This range of remedial options helps illustrate the special purpose of liability rules. Properly rule protection applies when the class of detainees is no more likely to contain dangerous enemies than any other group of people. Property rule protection is socially costless in such situations. At the other extreme, if each detainee is probably an enemy agent, they receive no protection. Liability rules are reserved for the intermediate and most difficult case: a detention reasonably calculated to bring in genuine threats to national security, but also certain to sweep in perfectly innocent people. The mixed nature of this situation - halfway between wholly illegitimate detentions and perfectly acceptable exercises of the police power - shows that the remedies reserved for the polar situations would be mismatched when applied to the intermediate one. Pliability does not shoehorn a case into a remedy designed for an entirely different situation. By keeping all the remedial options open, it allows the right tool to be used for the right task. 
Once the liability phase of the pliability rule kicks in, it works like a Takings rule applied to liberty rights instead of property rights. ${ }^{67}$ A detainee could challenge the constitutionality of his confinement. If the reviewing court finds that the government violated the constitution, it would order damages as the sole remedy. ${ }^{68}$ Detainees would receive compensation on a continuous basis for the duration of their confinement. The presumption of innocence would apply: each detainee would be entitled to compensation until and unless the government proves charges against him.

The pliability rule could be open-ended — with liability rule protection in effect indefinitely. Or a more cautious pliability rule could also be crafted under which the liability rules would expire after a certain time. The duration could be determined either through statute, or as part of the judicial decision to switch to the liability phase. Because the heightened transaction costs of mass detentions are largely the product of a need for swift action, they are also inherently short-lived. Thus the pliability rule contemplates a prompt reversion to property rule protection. For example, the judgment could say

\footnotetext{
${ }^{67}$ The Takings Clause serves as a model only in its broad outlines. The particulars of Takings Clause jurisprudence need not carry over to takings of non-property interests. Indeed, a straightforward application of eminent domain law to takings of liberty under a pliability rule would have absurd consequences. For example, if the Court were to award compensation only for "complete" rather than partial taking of liberty, it could mean that damages would only be paid to people detained for life, or confined in an isolation tank.

${ }^{68}$ Switching to the liability rule would not require a suspension of habeas corpus. True, the habeas corpus statute specifically allows those detained in violation of the Constitution to sue for immediate release, and thus, apparently mandates pure property rule protection for all unconstitutional takings of liberty. 28 U.S.C. $\S 2255$ (2003). But habeas would not conflict with the pliability rule because, as shown in Part IV, the Constitution itself does not require a property rule remedy. Under the pliability rule, a detainee who successfully challenges his confinement during the liability rule phase and is awarded damages has all the relief to which he is constitutionally entitled. The payment of damages under a liability rule cures the constitutional violation just as surely as an injunction cures it under a property rule. Moreover, habeas can complement the pliability system. In executive detentions - as opposed to those that result from judicial convictions - habeas will be the mechanism for challenging the substantive legality of the detention, with damages and not release as the remedy. This might require modest modifications in the habeas statute, but not necessarily. See Peyton v. Rowe, 391 U.S. 54, 66-67 (1968) ("[T]he [habeas] statute does not deny use of federal courts power to fashion appropriate relief other than immediate release."). Furthermore, the backend of the liability rule phase (the switch back to property rules) can be monitored by allowing detainees to seek habeas on the grounds that the emergency has subsided and thus, the legal protection of the liberty interest should revert to the default property rule, which would entitlethe petitioner to release.
} 
protection switches to liability rules, proceed to award damages, and further provide that after six months the protection reverts to a property rule. At that time, detainees would have to be released instead of being financially compensated.

Finally, implementing pliability rules in practice would be facilitated by legislation, if only to overcome sovereign immunity. ${ }^{69}$ Constitutionally-based damage claims against the government are barred by sovereign immunity, which current legislation only waives in Takings Clause cases. ${ }^{70}$ The statute allowing for compensation could also define with specificity the triggering events, establish a damages schedule, and resolve other procedural and administrative matters. Concerns about undercompensation could be met by allowing damages for the "inherent" harm of having a constitutional right violated.

\section{SUPERiority OF CONSTITUTional Pliability RUleS}

This Part explains the benefits of the pliability rule described in II.B. These benefits are relative to the property rule status quo, and this Part will frequently refer to the downsides of property rule protection in mass detention situations. The benefits are of three kinds. One set would be enjoyed by the detainees themselves. Under current

\footnotetext{
${ }^{69}$ Courts could presumably award damages through a Bivens remedy against the offending officials instead of enjoining them, without any Congressional authorization. See supra Part IV.C.3. Legislative compensation would be preferable, however, because it is unlikely that courts would be willing to financially ruin officials charged with implementing security measures, and even if they were, a remedy against officials might prove less financially satisfactory, as well as perhaps lacking some of the expressive and symbolic benefits of a remedy against the government itself. See supra Part III.B.

${ }^{70}$ Clark v. Library of Congress, 750 F.2d 89, 103 (D.C. Cir. 1984) (holding that sovereign immunity only permits injunctive and declaratory actions against government officials sued in their official capacity and noting that "courts have uniformly held that jurisdiction under the 'founded upon the constitution' grant of the Tucker Act is limited to claims under the 'takings clause' of the Fifth Amendment".).
} 
practice, despite the nominal availability of property rule protection, innocent detainees most often receive no judicial relief whatsoever. Under the system proposed in this Article, detainees would have a much greater certainty of receiving meaningful redress, while also being freed from the social stigma of detention. A second set of benefits would be enjoyed by society at large, which would receive the safety benefits of mass detentions while being spared some of the social discord caused by uncompensated detentions. A final type of benefit would redound to the legal system itself. The Court would be able to call constitutional shots as it sees them, without having to worry about reaching a substantive holding that would risk the massive social costs that might ensue from an injunction releasing the detainees.

\section{A. Remedial Continuity.}

\section{1) Hedging undiversified risks.}

Under a property rule, constitutional "balancing" resolves conflicts between competing legitimate interests by deciding which interest trumps; the winning interest receives property rule protection, the losing one must give way entirely. The all-ornothing dichotomy of property rules does not necessarily reflect the underlying balance of interests, especially in close cases. For example, if a massive individual rights interest outweighs an only slightly less substantial social interest, the social interest will receive as little protection as if it were entirely fanciful.

Pliability gives courts a way to significantly vindicate both competing interests instead of having to choose between them. ${ }^{71}$ Such a compromise solution would be

\footnotetext{
${ }^{71}$ See Bell \& Parchomovsky, supra note___, at 67-68.
} 
preferable to property rules in high-stakes situations like mass detentions, where the consequences of entirely sacrificing the liberty or social interest seem unacceptable. Of course, one might think this proves too much: the "all or nothing" dichotomy of property rules is not unique to mass detention situations. To better understand the benefits of pliability rules, this subsection will look more closely at the differences between mass detentions and the more routine cases of unlawful arrest and imprisonment.

Several things change in a national security emergency. The stakes on both sides of the constitutional balance are many orders of magnitude greater than in routine cases. On one side, thousands of people are detained, not just one. On the other side, thousands of people may be killed if there are no detentions. Furthermore, the likelihood of judicial error is much higher than in the ordinary context. Judges know cops and their abuses, as well as criminals and their subterfuges. Enemy agents, military necessities, and similar security matters are far outside judges' expertise, as courts frequently stress in national security cases. ${ }^{72}$ The shortness of time in which to deliberate further increases the probability of error. Thus, judges will have better understand when an arrest is justified than they will about a mass detention. ${ }^{73}$

${ }^{72}$ See CIA \& NSA: The Continuing Viability of the 1875 Supreme Court Case of Totten v. United States, 53 ADMIN. L. REV. 1273, 1277 \& n. 18 (2001) (“As judicial opinions have consistently acknowledged, courts lack the expertise to evaluate national security issues.”) (citing cases).

73

Evaluation of the government's interest here . . . would require the judiciary to draw conclusions about the operation of the most sophisticated electronic systems ... An intelligent inquiry of this sort would require access to the most sensitive technical information, and background knowledge of the range of intelligence operations that cannot easily be presented in the single "case or controversy" to which courts are confined. Even with sufficient information, courts obviously lack the expertise needed for its evaluation. Judges can understand the operation of a subpoena more readily than that of a satellite. In short, questions of national security . . . are of a kind for which the Judiciary has neither aptitude, facilities nor responsibility.

United States v. Morison, 844 F.2d 1057, 1082-83 (4 ${ }^{\text {th }}$ Cir. 1988) (Wilkinson, J., concurring) (emphasis added). 
Finally, in the ordinary non-crisis context, there are many cases with similarlysized stakes. While the property rule is all-or-nothing in a given case, error costs can be spread across cases, with some rules favoring the government, and others favoring individual rights-holders. This allows for risk-hedging on a macro level, and reduces the need for a mechanism that would balance competing interest within a single case. Put differently, in the everyday, non-crisis context, society holds a broadly diversified portfolio of relatively low-stakes constitutional risk. This diversification reduces the need for compensation for governmental takings. ${ }^{74}$ Indeed, diversification explains why compensation is required for takings of land but not for regulatory takings. Individuals hold a diversified portfolio of potential regulatory interests: some regulations may benefit them, some may harm them, but ex ante there is no reason to think there will be a systemic individual loss. However, most people have an entirely undiversified real property portfolio, and cannot insure themselves against losses due to eminent domain. ${ }^{75}$ Nationals security risk cannot be easily diversified, either by individuals or society. Security crisis are infrequent, and involve both individual and social stakes that dwarf other situations. Thus, the risk of error in either direction (overprotective or underprotective of liberty) cannot be spread across cases, and this raises the costs of

\footnotetext{
${ }^{74}$ See Louis Kaplow, An Economic Analysis of Legal Transitions, 99 HARV. L. REV. 509, 603 (1986).

$75[\mathrm{~F}]$ or many individuals and businesses, real property constitutes a large percentage of the value of all the capital assets they own. For them, a takings rule that never requires compensation on the theory that diversification can eliminate the risk ignores the reality that holdings in real property, as opposed to holdings in corporate stocks, for example, are not readily diversifiable due to the prohibitive expense of diversification.

Christopher B. Horn, Note, Capital Asset Pricing Theory and the Risk Of Government Regulation: Who Needs The Takings Clause Anyway?, 1995 U. ILL. L. REV. 945, 957 (1995). There are many reasons, such as moral hazard and adverse selection, that make private third-party takings insurance unfeasible. See Daniel Farber, Economic Analysis of Just Compensation Law, 12 INT'L REV. L. \& ECON. 125, 127-28 (1992) (reviewing various explanations for lack of private takings insurance and finding them "moderately persuasive.").
} 
error. Pliability rules serve as insurance against such catastrophic losses. ${ }^{76}$ They are a way of hedging against judicial error, and thus, useful when there is a heightened likelihood of mistakes and the mistakes are particularly costly. Sudden massive costs impose greater disutility than when the same amount of cost is spread out over time. Utility increases when volatile streams of costs and benefits are smoothed out. ${ }^{77}$ Pliability makes the set of remedies more continuous, and this lets courts reduce the volatility of outcomes for both society and individuals.

More concretely, pliability frees society from the potentially catastrophic results of an enjoined mass detention, but society pays for this safety in cash. (This lesser cost can be spread over time through government bonds.) The detainees are freed from the prospect of a massive uncompensated loss of liberty, but receive a less-than-fully compensatory damage remedy. Both sides are protected against their worst case scenarios, and in a situation marked by a high likelihood of error, such a hedge should make all parties better off than under the all-or-nothing approach.

\section{2) Optimizing on two axes.}

The dynamic relation between rights and remedies suggests a further benefit of pliability in the constitutional context, one that scholars have been entirely ignored. Constitutional rights can be understood as the product of two variables: the substantive definition of the right (the entitlement) and the protective rule (the remedy). Injunctive essentialism, by mandating property rules in all situations, prevents any adjustment of the

\footnotetext{
${ }^{76}$ See Lawrence Blume \& Daniel L. Rubinfeld, Compensation for Takings: An Economic Analysis, 72 CAL. L. REV. 569, 608 (1984) (showing why compensation for takings particularly important risk of loss cannot be diversified).

${ }^{77}$ See id. at 601-03 (illustrating economic concept of risk aversion in a takings context).
} 
remedial axis. As a result, to achieve the optimal level of a constitutional right, courts can only make adjustments on the substantive axis. Thus constitutional law in effect treats a two-dimensional optimization problem as a simple one-variable problem.

However, sometimes the proper balance between multifaceted competing interests can only be struck by adjusting both axes. Pliability allows for competing interests to be balanced along two axes simultaneously — the substantive doctrinal axis and the remedial axis. In situations where striking the optima balance between social and individual rights is difficult and the costs of erring in either direction particularly high, introducing an additional axis of optimization can achieve desirable outcomes that would be impossible under a pure property rule.

A numerical example will best illustrate this point. ${ }^{78}$ The actual level of protection of a constitutional right will be represented as $x$. It is a product of the scope and strength of the right $(s)$ and the remedial rule attached to it $(r)$, so that $s r=x$. The optimal level of protection has some objective value, $x^{*}$, which represents the best balance between individual rights and social interests. $s$ describes the substantive dimension of the right. For example, numerous exceptions to a right would lower $s$; on the other hand, a right with various prophylactic and penumbral rights attached (like the right against selfincrimination), has a higher $s$-value. This variable also captures the level of scrutiny with which a court will examine alleged infringements of the right: strict scrutiny results in a higher $s$ than rational basis review. Under a pure property rule, the robustness of the remedy is fixed at $r=1$ (on a zero to one scale, with zero being no remedy at all), while a liability rule puts $r$ somewhere between zero and one, depending on how close money

\footnotetext{
${ }^{78}$ The numerical values used in the example do not refer to any particular constitutional entitlement or factual situation, and are chosen purely for ease of illustration. The argument made herein does not depend on these particular values for $r, s$, and $x$.
} 
damages come to full compensation. To simplify the numerical example below, assume that under a liability rule $r=0.5$ (halfway between property and police power rules). The analysis below would work for any values of $r$, and 0.5 is chosen simply to make the example easier to follow.

At first glance, a court can reach the optimal degree of protection even with $r$ fixed at 1 simply by setting $s$ equal to $x^{*}$. However, the optimal degree of protection will vary across situations, requiring adjustments of $s$. This is where the problem arises. Courts cannot freely adjust $s$ to equal $x^{*}$ for all possible values that $x^{*}$ might take in different situations. In other words, courts do not have perfect continuity over $s$. Several factors suggest that the Court might only be able to choose from a discontinuous set of values for s, such as the imprecision of language and the potential lack of a five-justice consensus as to the proper $s$. Furthermore, stare decisis means that the choice of $s$ in one case limits the values $s$ can take in subsequent cases. And similar cases my be filed in several district courts, and heard on appeal by different circuit courts; the possible values for $s$ will also be limited by the values assigned to $s$ by conflicting lower court decisions.

Normally the incremental development of constitutional law brings $s$ close to $x^{*}$. A sudden radical change in circumstances - such as a national security emergency could result in a new $x^{*}$. The Court may not be able to compensate quickly enough by adjusting $s$ to equal the new $x^{*}$, at least not without doing violence to its precedents.

The Court's constitutional jurisprudence suggests than an assumption of four values for $s$ is realistic — high, medium, low, and zero. Assume that in a given situation, the optimal level of protection is $x^{*}=9$. The court can choose between four values of $s$ : zero (0), low (6), medium (12), and high (18). If the strength of the remedy is fixed at 1 , 
the court will be unable to achieve the optimal degree of protection — it will either be insufficiently protective by three degrees, or overly protective by three degrees. Pliability rules solve this problem by allowing the court to choose between property rule protection (1) and liability rule protection (0.5). Now the court can achieve the ideal level of protection for the constitutional right by defining the scope of the right broadly (the "high" level of 18), and using a liability rule to protect the right.

One might think this example proves too much. If remedial flexibility improves the Court's ability to set the optimal level of constitutional protection, it suggests liability rules should be an option in all cases. There are at least two responses to this objection. First, the numerical example is only intended to show that sometimes flexibility on $s$ will not be enough to optimize $x$. This does not mean that this will commonly be true. Indeed, one might think that the gradual development of constitutional law brings $s$ asymptotically close to $x^{*}$ in the typical case. The above example will most likely arise in a case of radically changed circumstances - that is, where ${ }^{*}$ suddenly leaps or plummets. Stare decisis may make it difficult for the Court to make $s$ leap or plummet by the same increment, at least without doing violence to constitutional doctrine and establishing precedents that will unduly constrict rights in times of tranquility.

\section{B. Redress for Detainees.}

The pliability rule would result in better treatment for detainees. Currently, a judge must decide whether to extend absolute protection or none at all, and in the midst of a security crisis, courts frequently give no protection at all, as shown in Part II.A1. Pliability rules would allow courts to grant meaningful relief, because they would not be 
deterred by the prospect of being held responsible for massive social costs if one of the released detainees commits an act of terror or sabotage.

The pliability rule would also provide superior protection for other intangible interests related to the liberty entitlement. The taking of the detainees' liberty is compounded with the public taint of disloyalty. ${ }^{79}$ Such public perceptions cannot be easily changed with ex post apologies and exonerations. The pliability approach allows the Court to declare the detention program unconstitutional (but without requiring an injunctive relief), thus, underlining the presumptive innocence of the detainees.Indeed, some commentators argue that a judicial vindication of constitutional rights - a finding that the government acted unconstitutionally against the detainees - has an inherent value to the victims, ${ }^{80}$ just as constitutional violations may have an inherent harmfulness outside any specific injury that they inflict. Under the current remedial regime, the Court finds it impossible to afford even this modest redress to detainees because it requires finding a constitutional violation, which under the injunctive essentialist paradigm, would require the release of the detainees, a cost the Court is unwilling to impose on society.

This Article does not contend that redress under liability rules will only be afforded in situations where there would be no redress under property rules. There may be situations where a court that would have been prepared with some reluctance to enjoin detentions will instead choose to limit the detainees to money damages. This would not represent a failure or weakness of the pliability rule regime. As this Article argues in Part

\footnotetext{
${ }^{79}$ See Hirabayashi v. United States. 828 F.2d 591, 593 (9th Cir. 1987) (observing that Japanese internment orders caused decades of "shame" for the detainees).

${ }^{80}$ See Bernard P. Dauenhauer \& Michael L. Wells, Corrective Justice And Constitutional Torts, 35 GA. L. REV. 903, 926 -927 (2001) ("In constitutional tort cases, a judicial finding in favor of the plaintiff is itself an essential part of the reparation that corrective justice requires. Through it, the state repudiates the violation of the direct victim's rights.").
} 
III.A., liability protection may be superior to property rule protection in such situations because it allows a more nuanced balancing of security interests against liberty interests, and this may come at the occasional price of a less compensatory remedy. However, based on past experience, and the institutional and psychological characteristics of courts, one would predict that under a pliability rule regime damages would more often be a substitute for no relief than for injunctive relief.

\section{Preserving Doctrinal Purity.}

As Part II.A has shown, the Court has in practice taken one of two courses when faced with a mass detention justified by a plausible national security interest. One course is abstention - avoiding a decision of the constitutional issue, at least until the crisis has abated. Aside from doing the detainees little good, this abstention prevents the development of a constitutional jurisprudence that could guide lower courts and the executive in times of crisis. The only other option for a court that wants to avoid the injunctive remedy is to deny the existence of the right — and this approach distorts constitutional doctrine, for the narrow precedents established in times of crisis will continue to have a backward pull on the liberty interest in times of calm.

While remedies are inflexible under the property rule assumption, substantive constitutional doctrine, with its open-ended balancing tests is notoriously malleable.

Thus,the remedial rule that will be applied shapes the definition of the initial entitlement. As Bhagwat has observed, when faced with a situation where vindicating rights requires "imposing unacceptable social costs," courts will more likely tweak constitutional 
doctrine thus, "distorting substantive law." ${ }^{81}$ Because of stare decisis, the Court's narrow interpretation of substantive constitutional rights in time of emergency will persist long after the crisis passes as "a loaded weapon ready for the hand of any authority that can bring forward a claim of plausible need," as Justice Jackson warned in Korematsu ${ }^{82}$ Thus, the tendency to uphold mass detentions — a tendency reinforced by the dominant property rule framework — limits the rights not just of the detainees themselves, but also threatens to establish principles that will reduce the freedoms of countless citizens in ordinary times. This phenomenon can be expressed in terms of the numerical illustration in III.A. Because the Court must make all adjustments on $s$, the sudden change in $x^{*}$ characteristic of national security emergencies means that setting $s=x^{*}$ during the emergency will mean that $s=x<x^{*}$ after the emergency. Since under a property rule $r=$ 1 , the post-emergency rights equilibrium will be simply the emergency-level $s$.

The severity of this doctrine-deforming effect is unclear. There are enough degrees of freedom in constitutional adjudication that peacetime cases may well have come out the same way they would have in the absence of the liberty-restricting wartime precedents. Indeed, the law has tools to limit, but not eliminate, the erosion of rights that Justice Jackson feared. Stare decisis only requires that a holding be applied to similar cases, and one could easily argue that a decision reached in time of emergency says

\footnotetext{
${ }^{81}$ Bhagwat, supra_note _ , at 1009. This important phenomenon has been ignored even by Merrill, one of the few scholars to entertain the possibility of using liability rules to protect constitutional entitlements. Merrill assumes that constitutional entitlements are static, unlike those of the common law, because "the authoritative constitutional text establishes the menu of entitlements." Merrill, supra note _, at 1152. However, the constitutional text is open-ended enough to give judges considerable flexibility in determining the scope of the entitlement, which can amount to determining whether the entitlement exists at all in a particular context. This is particularly true of commercial speech, the doctrine Merrill focuses on. Its nebulous status as a less protected speech right makes its borders elastic. Were the government allowed to eliminate tobacco advertising by "condemning" it and paying liability, as Merrill suggests, courts might strengthen the commercial speech right itself.

${ }^{82}$ See 323 U.S. at 246 (Jackson, J., dissenting).
} 
nothing about the scope of rights under normal circumstances. For example, the legacy of Korematsu shows that the doctrinal distortions can be largely smoothed out in subsequent peacetime cases, but some effects will linger and appear in surprising contexts. The Court became more suspicious of racial classifications in the decades after Korematsu than it had ever been before. Yet this salutary development was most likely due to changes in social attitudes and the composition of the Court, and might merely show that "the loaded weapon" can be disarmed. And there is evidence that even a decision as reviled as Korematsu shapes constitutional doctrine even to this day. The case came to be used to justify racial classifications under far less exigent peacetime circumstances, thereby fulfilling Justice Jackson's prophecy that it would "expand" to "new purposes." Thus even liberal justices invoke Korematsu as support for the constitutionality of race-based admission systems at public universities. ${ }^{83}$

Pliability rules reduce the pressure on the Court to pull its doctrinal punches in times of crisis. Once the liability phase kicks in, the Court can define substantive constitutional rights as expansively as it sees fit without worrying about imposing potentially disastrous social costs ${ }^{84}$ Because the switch from property to liability rule is a remedial adjustment, it has no stare decisis effects. Thus pliability cabins the effects of

\footnotetext{
${ }^{83}$ See Regents of University of California v. Bakke, 438 U.S. 265, 290-91, 299 (1978) (plurality opinion); $i d$. at 356 (Brennan, J., dissenting in relevant part).

${ }^{84}$ Bhagwat, who primarily urges using equitable discretion to deny injunctions in hard cases as a means of preserving doctrinal flexibility, briefly notes the possibility of money damages as an alternative. See Bhagwat, supra note _, at $101 \&$ n.212 (arguing for extension of C\&M framework to constitutional rights "under limited circumstances". This Article contributes at least two important elements left out of Bhagwat's analysis. First, Bhagwat does not identify or analyze the sources of extraordinary transaction costs in the constitutional setting. Carefully identifying these costs is necessary to define the kinds of situations where one would want liability rules. Second, Bhagwat ignores the possibility of pliability rules. By relating the previously-identified heightened transaction costs to a liability-rule "triggering" event, pliability allows for a principled, predictable and rule-like choice between property and liability rules, instead of leaving it as a matter of ad hoc judgment. Similarly, pliability rules mark not just the beginning but the end of liability rule protection, thus ensuring that money damages in lieu of injunctions are reserved for the truly "hard cases," as Bhagwat calls them.
} 
crisis decision-making to the crisis cases themselves. By contrast, when the Court avoids issuing an injunction by restrictively interpreting the constitutional right, it binds lower courts in future cases because the balancing of interests is expressed as a substantive judgment about the scope of the right. ${ }^{85}$

Professor Jeffries has made a related argument in defense of qualified immunity, which prevents plaintiffs from recovering money damages for constitutional violations. ${ }^{86}$ Awarding damages for constitutional violations, especially of newly-established rights, would put too high a "price tag" on rights-expanding decisions. ${ }^{87}$ That is, while the Court may be willing to expand the definition of a right or create a new one when such a decision is costless, it might not do so when it would impose a ruinous financial burden on municipalities. "Decoupling” constitutional violations from money damages "reduce[s] the cost of constitutional innovation, thereby advancing the growth of and development of constitutional law." ${ }^{88}$ Conversely, the costs of requiring "full remediation" would cause the Court to "constrict the future of constitutional law."

There are notable differences between pliability rules and sovereign immunity as mechanisms for doctrinal development, differences which underscore the merits of the former. First, sovereign immunity is far too broad to efficiently serve the purposes Jeffries attributes to it. It blocks relief in small cases as well as large, with no consideration of whether the damages "price tag" would paralyze constitutional law. Thus, any benefi cial effects on doctrine will most likely be felt only in a small portion of

\footnotetext{
${ }^{85}$ See Bhagwat, supra note _, at 1009.

${ }^{86}$ See John C. Jeffries, Jr., The Right-Remedy Gap in Constitutional Law, 109 YALE L.J. 87 (1999).

${ }^{87} I d$. at 101.

${ }^{88} I d$. at $103,98$.

${ }^{89} I d$.
} 
cases where sovereign immunity blocks relief. Pliability rules, in contrast, identify those cases where the "price tag" would likely result in doctrinal distortion, and lower the price of straight adjudication only in those cases.

Pliability rules allow for doctrinal growth by substituting monetary for injunctive relief; sovereign immunity substitutes no relief for money damages. Thus, the approach endorsed by Jeffries only advances one interest — doctrinal development — while entirely denying plaintiffs redress for their injuries. Pliability rules, in contrast, helps doctrine but not at the expense of wronged plaintiffs. Constitutional doctrine is a public good, like any judicial precedent. That is a sound argument for spreading the costs of its creation evenly across the public through taxation and compensation.

Indeed, one could imagine doctrine being stunted more by a shift from liability protection to no protection than by a shift from property protection to liability protection. Under a qualified immunity rule, plaintiffs with retrospective grievances know they cannot recover, and so they will not sue at all. While a suit would give the court occasion to define the scope of the constitutional right, this doctrinal public good would be largely subsidized by the plaintiffs, who would receive none of the benefits. ${ }^{90}$ Thus, the opportunities for doctrinal development will be greatly reduced. (But not, of course, eliminated, as evidenced by the large number of suits barred by qualified immunity.) After a shift from a property to a liability rule, plaintiffs still have ample incentive to

\footnotetext{
${ }^{90}$ See William M. Landes \& Richard A. Posner, Adjudication as a Private Good, 8 J. LEGAL STUD. 235, 240 (1979) (arguing that since judicial precedents that result from litigation are public goods, private litigants lack full incentives to provide optimal amount of precedent). To be sure, much constitutional litigation is undertaken by public interest law firms. Unlike individual plaintiffs, these groups are not interested in monetary relief as much as the establishment of principles which as repeat players they will benefit from in future cases. As a result, official immunity does not chill constitutional litigation as much as it otherwise would.
} 
litigate, in the form of money damages. Thus,pliability may have a greater "doctrine developing" effect than qualified immunity.

Furthermore, it is not obvious that large damage awards represent the kind of massive social costs that would lead the Court to pull its punches on doctrinal issues. One might think that a major purpose of public funds would be to compensate victims of constitutional violations, and that funds can be allocated and saved for such purposes. ${ }^{91}$ In contrast, the pliability rule described in this Article would have bite in national security emergencies where the social costs include both massive loss of life and significant economic dislocation. However, the matter is entirely speculative because sovereign immunity has always blocked damage actions: there is no way to know how the Court would have decided difficult constitutional questions in the absence of sovereign immunity. ${ }^{92}$ One need not indulge in counterfactual speculation to see the results of pure property rules, because the injunctive essentialist paradigm has governed constitutional law at least since Ex parte Young and with particular force since the 1950 s..$^{93}$ The

\footnotetext{
${ }^{91}$ Jeffries disagrees with the contention made in this Part, as he denies that injunctions can "freeze the law" in the way he contends money damages can. Injunctions simply do not impose the same level of social costs, in his view: "there is no grave danger that an injunction will deter the legitimate and socially desirable business of government, since the prohibition can he aimed quite specifically at the objectionable conduct, with ways of resolving uncertainty readily at hand." Jeffries, supra note __, at 110 . This accurately describes the typical situation, but not the mass detention situation in which this Article urges the use of liability rules. In that context, an injunction would prevent potentially vital security measures which though they may run afoul of individual rights are arguably the essential "legitimate business of government." Furthermore, a court reviewing a mass detention undertaken in good faith has no way of tailoring the injunction to release only the truly innocent. It acts, contrary to Jeffries' description, under conditions of radical uncertainty. Due to the shortness of time, the standard judicial tools for "resolving uncertainty" - the production and presentation of evidence - cannot be employed. Thus, Jeffries is wrong about injunctions in situations like mass detentions, though in fairness it is not clear if he intended his observations to extend to such situations, as his article deals primarily with structural reform injunctions in prison-condition litigation. See id. at 111-12.

${ }^{92}$ Jeffries concedes that his argument depends on "conjecture," $i d$. at 102 , and thus, "there is no way to be sure" how important cases would have come out under a liability rule. Id. at 103.

${ }^{93}$ See Richard H. FAllon, JR., DANiel J. Meltzer, \& DAVID L. Shapiro, The Federal CourTS AND THE FEDERAL SYSTEM 856 (4th ed. 1996) (“[A]t least since Brown v. Board of Education . . injunctive
} 
reluctance of the Court to enjoin detentions under property rules is similarly manifest, though admittedly there are too few data points to say much with certainty.

Still, if one accepts Jeffries' argument about the deleterious effect of a high monetary price tag on judicial decision-making, one could see this as weakening the pliability rule's doctrinal effects. In the liability rule phase of a pliability rule, courts would order compensation, and this would require a narrow statutory waiver of sovereign immunity. Compensation may be expensive, ${ }^{94}$ and this itself might lead the Court to distort substantive doctrine. Given the speculative nature of this phenomenon, such an effect cannot be ruled out. However, the doctrine-stifling effect of the pliability rule will be smaller than under a pure property rule, for the simple reason that social costs of a liability rule will be lower than the social costs of a property rule (this is the essence of the liability-phase triggering criterion). Thus, even if on e accepts Jeffries' views about the effects of damages on constitutional doctrine, pliability rules would be preferable to the current regime.

\section{Speed and Certainty.}

As has been shown above, the Court has sometimes used abstention to navigate between the unacceptable social costs of injunctions and the doctrinal costs of upholding mass detentions. Such abstention, which may be the least bad alternative under a property

remedies for constitutional violations have become the rue and actions at law (at least for damages) the exception.").

94 The pliability rule would not result in the kind of massive damages that Jeffries fears. The situations in which he sees a damage requirement as debilitating involve new constitutional rules that in effect create long-standing constitutional violations, like public school segregation. For example, if Brown resulted in the payment of damages to every black who attended or had attended a segregated school, the scope of liability would indeed be daunting. Jeffries, supra note __, at 101-102. Pliability rules, however, do not involve such retrospective rule changes, but rather the compensation of a discrete (though potentially large) number of individuals for constitutional violations in a delimited period of time that starts with the triggering of the liability rule and ends with the reversion to a property rule. 
rule, has at least two major costs. The pliability approach eliminates these problems by allowing the Court to declare a constitutional violation and remedy it through damages. This is an option that the Court would be likely to exercise because it gives the Court a way of doing its constitutional duty without upsetting important national security measures (a social cost they are unwilling to impose).

First, under the abstention strategy, detainees have their liberty appropriated while the Court bides its time. Even if the Court ultimately enjoins the detention program after the crisis, the intervening years of detention represent an uncompensated taking of liberty not remedied by the subsequent injunction. Thus, Korematsu's refusal to adjudicate the detention order in effect countenanced a temporary taking of liberty without compensation, as recognized by one of the dissents..$^{95}$ The same can be said of Milligan..$^{96}$ Second, Vallandigham-Hirabayashi abstention prevents the development of constitutional doctrine about the proper balancing of executive power and individual liberty in times of military emergency. While it is the Court's job to "say what the law is, ${ }^{97}$ it has failed to establish any framework for thinking about the constitutionality of

\footnotetext{
${ }^{95}$ See Korematsu, 323 U.S. at 233 (Roberts. J., dissenting) ("It is a new doctrine of constitutional law that one indicted for disobedience to an unconstitutional statute may not defend on the ground of the invalidity of the statute but must obey it though he knows it is no law and, after he has suffered the disgrace of conviction and lost his liberty by sentence, then, and not before, seek, from within prison walls, to test the validity of the law.").

${ }^{96}$ See REHNQUIST, supra note __, at 222 (noting that Milligan languished in jail for years as a result of the Court's abstention policy). Indeed, Milligan had been condemned to death by the military commission the Court subsequently held unconstitutional. He received an eleventh-hour reprieve, but one doubts whether the Court's subsequent issuance of habeas - very much a property rule remedy - fully compensated him for his unconstitutional detention. Here, pliability rules would most probably have left Milligan much better off than the pure property rule regime the Court operates under.

${ }^{97}$ Marbury v. Madison, 5 U.S. (1 Cranch) 137, 177 (1803) (Marshall, C.J.).
} 
mass detentions. The justices have been famously described as "teachers in a vital national seminar. ${ }^{, 98}$ However, in mass detention situations, class has not been in session.

One has little idea of what factors the Court will weigh in assessing the constitutionality of a detention program, or their relative importance. Do detentions fare better if directed at ideological groups, as in the Civil War, instead of ethnic groups, as in WWII? Does there need to be an actual war, or just pending hostilities? Are detentions of ethnic groups not subject to widespread bigotry, like Anglo-Saxons, easier to sustain than those directed at "discrete and insular minorities"? Is virtually any good faith detention program permissible once the nation has been attacked — or does no emergency at all justify such measures? How much extra leeway does the executive get from bringing unrelated criminal or immigration charges against national security detainees? One can only speculate, and one must speculate because the Court has kept its counsel.

As a result, an Executive solicitous of civil liberties has no way of knowing how to structure a detention policy — short of foregoing detention altogether — in a way that minimizes its potential unconstitutionality. The Executive has sole responsibility for protecting national security, and only a shared and subordinate responsibility for interpreting the Constitution. So a President in a military emergency, without any firm judicial precedent on the scope of rights in such situations, will focus on vindicating security interests and leave constitutional doubts to the courts. Attorney General Francis Biddle later wrote "the constitutional difficulty" of the internments did not seem to worry President Roosevelt. "That was a question of law, which ultimately the Supreme Court must decide. And meanwhile - probably a long meanwhile — we must get on with the

\footnotetext{
${ }^{98}$ Eugene V. Rostow, The Democratic Character of Judicial Review, 66 HARV. L. REV. 193, 208 (1952).
} 
war." ${ }^{99}$ This shows that presidents can anticipate and exploit the Court's procrastination. On the other hand, it also suggests Roosevelt would have heeded judicial guidance had it been available. He was wrong about one thing. A Supreme Court practicing abstention need not decide anything. Thus "meanwhile" has lasted to this very day.

\section{E. Deterrence.}

This subpart argues that a temporary switch to liability rules will not weaken the deterrent power of constitutional norms. The magnitude of the deterrent effect is hard to calculate, and it may be small. Of the two functions of tort damages - compensation and deterrence - constitutional liability rules will be much more certain of achieving the former than the latter. But even if the deterrent effect is negligible, this would not condemn pliability rule protection because it would be no lessa deterrent than pure property rule protection. ${ }^{100}$

First, we must consider whether property rules deter mass detentions. An injunction against such policies could greatly embarrass the political branches, and this may explain why they are in fact quite rare. While the Court has not blocked the few detention programs that have been implemented, the possibility that it might have done so may have prevented the creation of other detention programs, and this effect would be invisible to historians. Thus, property rules may deter not through their remedy, but through the expressive force of law. ${ }^{101}$ There is good reason to believe that property rules

\footnotetext{
${ }^{99}$ FRANCIS BIDDLE, IN BRIEF AUTHORITY 219 (1962) (emphasis added).

${ }^{100}$ Property rules make deterrence less important because they can actually stop prospective violations. Liability rules cannot do this, but this does not weaken the case for their use for mass detentions, which the Court has historically not blocked with injunctions.

${ }^{101}$ See Bhagwat, supra note __, at 1010 (observing that it is "more difficult . . . for a public official to defend an action that admittedly violates the Constitution, even if the courts will permit her to get away
} 
do not have such invisible deterrent effects. The political branches are surely aware of history, which demonstrates that the Court will defer to them in emergencies. Because the property rule is not enforced, it is hard to see how it could seriously deter.

Liability rules will do significantly better at deterring misconduct through the expressive function of law. In the liability phase, damages are only awarded when constitutional rights have been violated — that is, under the same circumstances that an injunction would issue under normal circumstances. However, the Court is much likelier to declare a constitutional violation under a liability rule than under a property rule because the perceived social cost of doing so is lower. By allowing the Court to call constitutional shots as it sees them, liability rules increase its ability to brand governmental actions as unconstitutional. Such a reprimand is a "political" cost that will be internalized by governmental actors even if economic costs are not, leading to increased deterrence ${ }^{102}$

Furthermore, a compensation requirement might have a greater deterrent effect than equitable relief because it hits governmental agencies in the pocketbook. This leaves the affected agencies worse off, while injunctions do not crimp their budget at all (at most they could be seen as causing a partial forfeiture of the administrative costs already sunk into the detention program). However, because the government does not fully internalize the financial costs of its actions, it is far from clear whether court-ordered compensation

with it, than an action that the official can plausibly argue is consistent with the Constitution."); Levinson, Rights Essentialism, supra note _, at 905 (suggesting that "constitutional rights may have an effect on government behavior independent of formal, state-imposed sanctions for noncompliance").

${ }^{102}$ Myriam E. Gilles, In Defense of Making Government Pay: The Deterrent Effect of Constitutional Tort Remedies, 35 GA. L. REV. 845, 860-61 (2001) (arguing that constitutional tort remedies deter by imposing political costs on government actors through exposing and publicizing unconstitutional actions). 
can significantly shape official behavior. ${ }^{103}$ The question is complex, and well beyond the scope of this Article. (If compensation can in theory deter governmental misconduct, the size of the deterrent effect would depend on the details of the compensation scheme such as the source of funds for the payments. ${ }^{104}$ There may well be ways of setting up a compensations scheme that would directly link economic costs with political costs, which are certainly internalized by governmental actors. ${ }^{105}$ ) Whatever the theoretical arguments about the deterrent effect of damages, it bears noting that Justice Department officials responsible for the September 11 detentions repeatedly expressed anxiety about their exposure to Bivens suits in internal deliberations. ${ }^{106}$

Some might worry that liability rules would encourage the government to go on a "shopping spree" for individual rights outside of mass detentions. Aside from the political and economic deterrents to such action, discussed above, the pliability rule creates a first line of defense through its "toggling" mechanism. This only allows a switch to liability rules when transaction costs become very high, and when the taking has a legitimate purpose. These circumstances are outside the government's control, and if the government attempts to "buy" rights outside of these circumstances, it will face an injunction. There is no reason to believe that the existence of a liability rule for narrowly-

\footnotetext{
${ }^{103}$ See Levinson, Making Government Pay, supra note __, at xxx. But see, Bhagwat, supra note __, at 1011 (suggesting that money damages can significantly deter future constitutional violations); AMAR, supra note __, at Xxx.

${ }^{104}$ Some current compensation statutes establish a trust fund that receives annual appropriations; these monies can only be used for compensation. See, e.g., 42 U.S.C. § 300aa-15(j) (2003) (establishing trust fund for vaccine injury compensation program and appropriating $\$ 110,000,000$ per year to the fund).

${ }^{105}$ For example, the compensation statute can impose a national tax that would only be levied when a court finds that the liability rule has been triggered. The revenue from the tax would fund the compensation payments. Voters would know that their higher taxes resulted from unconstitutional detentions. Such a scheme, while admittedly unusual, could significantly raise the political costs of detentions.

106 THE SEPTEMBER 11 DETAINEES, supra note __, at 55, 87, 96.
} 
defined classes of cases would reduce to Court's willingness to enjoin violations outside of the category that it would currently be prepared to enjoin.

\section{CONSTITUTIONALITY OF LIABILITY RULES}

This Part shows that the Constitution itself does not demand property rule protection for constitutional rights. While the general grant of federal question jurisdiction gives courts the power to issue injunctions, Congress can limit remedies for constitutional violations to legal ones, thus creating a liability rule. Moreover, the doctrine of equitable discretion lets courts refuse to enjoin a constitutional violation. Thus, the pliability rule proposed in this paper would be constitutional if implemented by the Court using its inherent powers, and a fortiori if Congress authorizes it. Part IV.A examines the Constitution's text and finds it only defines entitlements - the first step of the C\&M analysis - but has nothing to say the second step, the choice of protective rule. Part IV.B explains the doctrine of equitable discretion, which has been largely forgotten but not repudiated - in constitutional law. Equitable discretion means that even when all other prerequisites for invoking equity are met, the chancellor need not issue an injunction when it would seriously harm important public interests. Part IV.C shows the Court's constitutional remedies jurisprudence allows for constitutional liability rules, especially when explicitly created by Congress. Finally, Part IV.D showsconstitutional law has long countenanced pliability rules in situations with high transactions costs, though these doctrines have not been recognized as pliability rules. 


\section{A. Constitutional Text.}

The Constitution says next to nothing about how the entitlements it defines should be protected. Taken with Congress's power to regulate the jurisdiction of the courts, ${ }^{107}$ this suggests thatthe Constitution leaves remedies open to legislative experimentation. Congress has chosen to delegate much of this remedial discretion to the courts, under the broad grant of federal question jurisdiction. ${ }^{108}$ Yet it can be argued that the Constitution itself explicitly or implicitly rejects anything but property rules. These arguments will now be discussed, and ultimately rejected.

Most constitutional rights are phrased as absolute prohibitions on governmental conduct rather than as conditional protections. Liability rules are widely seen as "allowing" or condoning the "purchase" of constitutional rights. Some argue that policing these rights through liability rules would defy the Constitution itself by transforming the Bill of Rights from a collection of "the government shall nots" to "the government may, if it is prepared to pay." ${ }^{109}$ The first eight amendments' prohibitory tone may suggest the

${ }^{107}$ See U.S. CONST., art. III $\S 1$, cl. 1 (vesting judicial power in Supreme Court and lower courts that Congress may "ordain and establish") and art. III $\S 2$ (authorizing Congress to make "Exceptions" to and "regulations" of jurisdiction of Supreme Court, the only constitutionally created tribunal).

${ }^{108}$ See 28 U.S.C. 1331 (2003).

[The federal question] jurisdictional grant provides not only the authority to decide whether a cause of action is stated by a plaintiff's claim that he has been injured by a violation of the Constitution, but also the authority to choose among available judicial remedies in order to vindicate constitutional rights.

Bush v. Lucas, 462 U.S. 367, 374 (1983) (citation omitted). See also Mitchum v. Hurt, 73 F.3d 30, 35 (3d Cir. 1995) (assuming that federal courts power to grant injunctions and money damages both stem from statutory grant of federal question jurisdiction).

109

The language of the [fourth] amendment is an affirmative command. It is therefore doubtful that the substitution of a claim against the government for the exclusionary rule in all cases would provide equally effective vindication of the constitutional interests thus protected, and it is therefore doubtful that such a substitution would be constitutionally valid.

Dellinger, supra note __, at 1563. See also Levinson, Rights Essentialism, supra note _, at 859-60 (describing view that "remedies in constitutional law should be regarded primarily as sanctions rather than prices" for constitutional violations). 
general desirability of property rule protection for constitutional rights, but this tone alone does not delimit the range of constitutionally permissible remedies.

First, many laws are phrased as "shall nots," yet are enforced only through liability rules. The Supreme Court has recently recognized that defining protected interests is distinct from the judicial means for enforcing them, and that a statutorilydefined interest can leave open a menu of remedies for its enforcement: ${ }^{110}$ "A federal judge sitting as chancellor is not mechanically obligated to grant an injunction for every violation of law." "111 Oakland Cannabis did not involve constitutional rights, so it may leave open the argument that the Bill of Rights, unlike many statutes with mandatory language, represents a "flat command" 112 that can only be vindicated through injunctions. Determining whether a statutory command creates property rule protection requires a careful reading of the relevant command. Mandatory language points towards an equitable remedy, but does not dispose of the question. The explicit provision of legal remedies under the statute points the other way. ${ }^{113}$ This suggests thatinjuncti ons are not mandatory when ex post monetary damages could be paid to the victims. An unconstitutional taking of life would have to be enjoined, by analogy to the prospective

\footnotetext{
${ }^{110}$ United States v. Oakland Cannabis Buyers' Co-op., 532 U.S. 483, 497-98 (2001) (citations omitted) (“A district court cannot, for example, override Congress' policy choice, articulated in a statute, as to what behavior should be prohibited. [The district courts'] choice. . . is simply whether a particular means of enforcing the statute should be chosen over another permissible means.").

${ }^{111} I d$. at 313 .

${ }^{112}$ Weinberger v. Romero-Barcelo, 456 U.S. 305, 314 (1982).

${ }^{113} I d$. at 314-15 (holding that district court acted within its discretion in refusing to enjoin continued violation of environmental statute by Navy because the statute expressly provided for monetary damages).
} 
killing of the snail darters in TVA v. Hill. ${ }^{114}$ Deprivations of liberty such as mass

detentions, on the other hand, do not preclude monetary relief.

Second, the Constitution's "commands" are not for the courts' ears only. The two coordinate branches of government also have a vital role in interpreting the Constitution. ${ }^{115}$ While the Bill of Rights is more than a series of "pious exhortations or appeals to the forbearance" of the political branches, ${ }^{116}$ it is also that. Their preliminary duty to interpret and adhere to the Constitution makes the mandatory phrasing of the Bill of Rights meaningful even if violations of this language are protected in some circumstances by liability rules.

Some commentators have argued that the express provision of a liability rule for takings of property creates a negative implication that all other rights receive property rule protection. ${ }^{117}$ The negative implication argument proves too much. The Takings Clause is arguably the only provision in the Constitution that prescribes a remedy of any kind for its violation. ${ }^{118}$ Thus, the negative argument, if taken seriously, would lead to the

\footnotetext{
${ }^{114} 437$ U.S. 153, 193-94 (1978). See also Weinberger, 456 U.S. at 314 ("It was conceded in Hill that completion of the dam would eliminate an endangered species by destroying its critical habitat. . The purpose and language of the statute limited the remedies available to the District Court; only an injunction could vindicate the objectives of the Act.").

${ }^{115}$ See CURRIE, CONGRESS, supra note __, at ix (1997) ("Members of Congress and executive officers, no less than judges, swear to uphold the Constitution, and they interpret it every day in making and applying the law.").

${ }^{116}$ Roscoe Pound, The Development of Constitutional Guarantees of LiBerty 105 (1957).

${ }^{117}$ See, e.g., John O. McGinnis, The Once and Future Property-Based Vision of the First Amendment, 63 U. CHI. L. REV. 49, 76-77 (1996) (arguing that explicit allowance of liability rules for seizure of material property implies that property rule protection obtains for information property protected by the First Amendment).

118 The "safeguarding" of habeas against suspension could count as a second, presumably protected by a property rule. See Richard H. Fallon, Jr. \& Daniel J. Meltzer, New Law, Non-Retroactivity, and Constitutional Remedies, 104 HARV. L. REV. 1733, 1779 n. 244 (1991). Though commentators have apparently not noticed this, the Eighth Amendment's "excessive bail" provision could be read as requiring liability rule protection of the government's limited right to arrest people. It allows the suspect to "buy out" the government's entitlement, and much like that Takings Clause, requires a judicial appraisal of the
} 
absurd conclusion that the Constitution offers no judicial remedy at all for violations of other rights. The Court has never entertained such an implausible interpretation. To the contrary, it has found damage remedies implicitly available for a variety of constitutional rights. ${ }^{119}$ Injunctive remedies have been implied directly from the Constitution since $E x$ parte Young. ${ }^{120}$ Therefore the alternative to the negative inference is to see the Takings Clause as the only right whose remedy is constitutionally mandated, and for which no other remedy (such as injunctions) can be substituted. ${ }^{121}$

There is yet a related explanation for why the Constitution only provides an explicit remedy for Takings. The liability rule for takings might mean that sovereign immunity is automaticallytrumped for eminent domain, without the need for an explicit statutory waiver. ${ }^{122}$ Sovereign immunity does not bar injunctive relief, and thus, there entitlement's value to ensure fairness. (Though unlike the Takings Clause, it protects the entitlement taker from paying an overly high price, not the entitlement holder from receiving too low a price.)

${ }^{119}$ See Bivens v. Six Unknown Named Agents of Federal Bureau of Narcotics, 403 U.S. 388, 396-97 (1971) (allowing private action against federal officers for violating privacy right although "the Fourth Amendment does not in so many words provide for its enforcement by an award of money damages for the consequences of its violation"). Implied remedies have also been found under the First Amendment, see Butz v. Economou, 438 U.S. 478 (1978), the Due Process Clause of the Fifth Amendment, see Davis v. Passman, 442 U.S. 228 (1979), and the Eighth Amendment, see Carlson v. Green, 446 U.S. 14, 19 (1980) (holding that Court can imply damages remedy for constitutional violations by federal agents unless Congress provides an "alternative remedy" as a "substitute" to private recovery).

${ }^{120} 209$ U.S. 123, 155-56 (1908).

${ }^{121}$ See Fallon \& Meltzer, supra note __, at 1779 ("To the framers, special provision for constitutional remedies probably appeared unnecessary, because the Constitution presupposed a going legal system, with ample remedial mechanisms, in which constitutional guarantees would be implemented.")

${ }^{122}$ First English said that the just compensation requirement applied to states "of its own force, furnish[ing] a basis for a court to award money damages against the government." First English Evangelical Lutheran Church of Glendale v. County of Los Angeles, 482 U.S. 302, 316 \& n.9 (1987). First English involved a municipality, and thus, there would have been no sovereign immunity bar to the damage action in that case. However, "the Court's opinion did not rest on a distinction between local and state or federal governments, and the Court rejected the United States' position that, in light of sovereign immunity, the just compensation clause should not be interpreted to require a monetary remedy." Fallon \& Meltzer, supra note _, at $1826 \mathrm{n} .536$. The strong implication of the phrase "a basis for ... money damages" is that immunity is not an issue, and some federal appellate courts have understood this to apply to federal sovereign immunity as well. See Arnsberg v. United States, 757 F.2d 971, 980 n.9 (9th Cir 1984) (dicta) ("Actions brought under the taking clause of the fifth amendment are, of course, an exception to the rule that sovereign immunity is a bar to damages against the United States for direct constitutional violations."). 
would be no need for constitutional provisions to ensure that injunctions could be available. The sovereign immunity reading reaffirms that the Just Compensation Clause does not speak to whether injunctions are ever constitutionally required.

The Supreme Court has recognized these points when it left open the possibility that a constitutional provision's "prohibitory nature," standing alone, does not make the availability of a particular type of remedy for violation of a "right guaranteed by the Constitution." ${ }^{123}$ In First English, the Court suggested that Just Compensation language makes the remedy - money damages - mandatory upon a finding of a taking. ${ }^{124}$ In reaching that unsurprising conclusion, the Court rejected the state's argument that the "prohibitory nature" of the Fifth Amendment makes it only a limitation on the power of government action, and not a right coupled with a self-executing remedy. ${ }^{125}$ The Court's analysis suggests that only the express constitutional provision of a remedy makes the redress of a particular wrong by that particular remedy a "right guaranteed by the Constitution." ${ }^{126}$ Otherwise, rights are amenable to a range of constitutionally sound remedial regimes.

\footnotetext{
See also LaURenCe H. TRIBE, 1 AmERICAN Constitutional Law § 6-38, at 1272-73 (3d. ed. 2000) (“[A] sovereign immunity defense [] may not be available against a takings challenge, because the Court has suggested, although it has not clearly held, that the Fifth Amendment's Takings Clause trumps state (as well as federal) sovereign immunity.").

${ }^{123}$ First English, 482 U.S. at 315.

${ }^{124} \mathrm{Id}$. at $316 \mathrm{n} 9$ (1987). The Court has also held that money damages is the constitutionally required remedy for unconstitutional state taxes and thus, state sovereign immunity is no bar. See McKesson Corp. v. Division of Alcoholic Beverages \& Tobacco, 496 U.S. 18, 40-41 (1996). Thus, eminent domain and taxation are the only areas where the Court has held sovereign immunity inapplicable in suits for money damages. See Fallon \& Meltzer, supra note _, at 1825.

${ }^{125}$ First English, 482 U.S. at 316.

${ }^{126} I d$. at 315 .
} 


\section{B. Equitable Discretion.}

Injunctions are an extraordinary remedy - even in constitutional cases. The principles of equity jurisdiction apply to constitutional cases as much as to any other. ${ }^{127}$ The equitable discretion doctrine allows courts to refuse to issue an injunction on public interest grounds, even when the plaintiff has a prima facie case for equitable relief. ${ }^{128}$ This "balancing of the equities" approach "permits courts to grant relief, or to deny it, on an $a d$ hoc basis." 129 This of course is merely another way of saying that choosing constitutional remedies involves different and broader considerations than determining the substantive scope of the right, or in C\&M terms, setting the entitlement is distinct from determining what type of protection it receives. Equitable discretion does not disappear in constitutional cases, ${ }^{130}$ though it is used less often. ${ }^{131}$ For example, a recent case involving a challenge to post-September 11th security measures denied a preliminary injunction on

127 See Bivens, 403 U.S. at 403 (Harlan, J., concurring) (observing that injunction against constitutional violation appropriate only "if a proper showing can be made in terms of ordinary principles governing equitable remedies.")

128 Courts of equity. . . enjoy[] sound discretion to consider the "necessities of the public interest" when fashioning injunctive relief. . . Such discretion is displaced only by a "clear and valid legislative command. . . A grant of jurisdiction to issue hardly suggests an absolute duty to do so under any and all circumstances. Because the District Court's use of equitable power is not textually required by any "clear and valid legislative command," the court did not have to issue an injunction.

United States v. Oakland Cannabis Buyers' Co-op., 532 U.S. 483, 496-97 (2001) (citations omitted). See also Weinberger v. Romero-Barcelo, 456 U.S. 305, 312 (1982) ("In exercising their sound discretion, courts of equity should pay particular regard for the public consequences in employing the extraordinary remedy of injunction").

${ }^{129}$ See Bhagwat, supra note __, at 1007 (recommending that courts use equitable discretion to avoid injunctive remedies in constitutional cases where they would otherwise be under pressure to deny the existence of the claimed right).

${ }^{130}$ See, e.g., Babbitt v. United Farm Workers Nat. Union, 442 U.S. 289, 317 (1979) (noting that court can use equitable discretion to abstain from remedying a constitutional deprivation); Watson v. City of Memphis, 373 U.S. 526, 533 (1963) (suggesting that court could allow unconstitutional condition to persist if there are circumstances that "manifestly" warrant court's exercise of equitable discretion).

${ }^{131}$ See id. at 1012-13 (observing that use of equitable discretion "as a response to societal pressure is not entirely unknown in modern constitutional law, even though it has rarely been acknowledged," and offering the Brown decisions as examples). 
public interest grounds, finding that " $[\mathrm{b}]$ oth the Government and the public have a strong interest in curbing the escalating violence in the Middle East and its effects on the security of the United States and the world as a whole." ${ }^{132}$

\section{Legislative Restrictions on Equitable Relief.}

1) The obscure origins of injunctive essentialism.

Injunctive essentialism is a surprisingly new phenomenon, and so a consideration of its origins may help determine its proper limits. These origins turn out to be somewhat obscure. ${ }^{133}$ In Ex parte Young, the classic case establishing the federal courts' power to enjoin unconstitutional action by state officials, the Court simply assumed the availability of the remedy, without explaining its source. Young is in fact the Bivens of equitable relief, and vice versa. Bivens inferred its damages remedy against officials on the ground that certain remedies are presumptively applicable to constitutional injuries because those remedies are "normally available in the federal courts." However, Bivens left open the possibility, embraced in subsequent cases, ${ }^{134}$ that the presumptive availability of traditional remedies does not diminish Congress's power to substitute "[an]other remedy," so long as it is "equally effective in the view of Congress." 135

Given that, as the Court has held, Congress can replace the Bivens damages remedy even with a less attractive one (from the plaintiff's perspective) it would be odd to think that Congress could not provide a damages remedy as a "substitute" for an

\footnotetext{
${ }^{132}$ Holy Land Foundation for Relief \& Development v. Ashcroft, 219 F. Supp.2d 57, $84-85$ (D.D.C. 2002) (refusing to enjoin blocking order on Muslin foundation's funds, despite irreparable harm to plaintiff, because of public interest concerns and lack of likelihood of prevailing on merits).

${ }^{133}$ See FALlON, MELTZER, \& SHAPIRO, supra note _ , at 857 (observing that "there is little clear authority for a general right to anticipatory relief.")

${ }^{134}$ Bush v. Lucas, 462 U.S. 367, 378-80 (1983); Chappell v. Wallace, 462 U.S. 296, 302-04 (1983); Schweiker v. Chilicky, 487 U.S. 412, 425-27 (1988).

${ }^{135}$ Bivens, 403 U.S. at 397 (emphasis added); Carlson v. Green, 446 U.S. at 18-19.
} 
injunctive one. Thus, one would expect that the Court'sinsistence in Bivens that Congress can "presumptive" damages remedieswould also apply to thepresumptively available equitable remedy created by Bivens's progenitor, Young. The courts of appeals have held as much, agreeing that Congress can foreclose injunctions for constitutional violations just as surely as it can preempt the Bivens remedy. ${ }^{136}$

While Young did not clearly articulate the source of an equitable remedy for constitutional violations, it did give some good reasons for inferring one. In the case at hand, the criminal penalties for violating the challenged statute were so severe, the Court believed no one would risk violating the law to test its constitutionality in a retrospective suit. Without injunctive relief, there would be no judicial review at all. ${ }^{137}$ The justices appeared to think they were in the radical situation where a statute, in practical effect, entirely forecloses access to the courts. The Court has famously hinted that such an endrun around judicial review might be unconstitutional even during national security crises. ${ }^{138}$ The Court's discovery of an implied equitable remedy in Young would be a way of avoiding the problem. Seen this way, Young hardly establishes the presumptive availability of equitable relief insisted on by injunctive essentialism. In particular, in the

\footnotetext{
${ }^{136}$ See, e.g., Saul v. United States, 928 F.2d 829, 843 (9th Cir.1991); Stephens v. Dep't of Health \& Human Servs., 901 F.2d 1571, 1575-77 (11th Cir. 1990); Lombardi v. Small Business Administration, 889 F.2d 959, 962 (10th Cir. 1989). The Third Circuit has held that while there is "a good argument" that Congress can preempt equitable remedies for constitutional rights just as it can preempt damage remedies, the preemption would have to be more explicit in the former case because of the presumptive availability of injunctions against constitutional violations. Mitchum v. Hurt, 73 F3d. 30, 35-36 (3rd Cir. 1995). See also Hubbard v. E.P.A., 809 F.2d 1, 11 n.15 (D.C. Cir. 1986) (holding that while Congress "may limit" courts power to enjoin unconstitutional acts by the government, it must do so "explicitly," while Congressional limits on Bivens actions for damages can be implied from the existence of an alternative administrative remedy).

${ }^{137}$ See Young, 209 U.S. at 147.

${ }^{138}$ Ex parte McCardle, 74 U.S. 506, 515 (1868) (upholding limitations of Supreme Court's appellate jurisdiction, but noting in dicta that some avenues for securing review presumably remain).
} 
case of a liability rule for mass detentions, access to the courts would not be foreclosed. ${ }^{139}$ Indeed, since the detainees would already have been arrested, they would have every incentive to challenge their confinement. Equity would not be the only way for them to secure judicial review.

The ascendance of injunctive essentialism, given such murky origins, may best be understood as an artifact of sovereign immunity in damages suits. To paraphrase Justice Harlan's concurrence in Bivens, for the typical plaintiff facing a deprivation of constitutional rights, the alternatives have traditionally been an injunction or nothing. ${ }^{140}$ Historically, equitable remedies were needed not because the remedy at law was arguably inadequate, but because it was obviously nonexistent. Bivens itself changed that, but injunctive essentialism has failed to take account of the post-Bivens remedial situation. The availability of some remedy at law should weaken the need for anticipatory relief. Moreover, this account of injunctive essentialism suggests that if Congress waives sovereign immunity for certain types of constitutional violations, the argument for the mandatory nature of injunctive relief weakens considerably. So if Congress allows for damage suits by detainees, as this Article recommends, many of the assumptions underpinning injunctive essentialism drop out.

\section{2) Tax Injunction Act.}

The Tax Injunction Act ("TIA") explicitly prohibits injunctions against the assessment or collection of state taxes "where a plain, speedy and efficient remedy may

\footnotetext{
${ }^{139}$ Cf. Thunder Basin Coal Co. v. Reich, 510 U.S. 200, 212-213, 218 (1994).

140 See 403 U.S. at 410 ("For people in Bivens' shoes, it is damages or nothing.").
} 
be had" in the state's courts. ${ }^{141}$ Federal courts have repeatedly held that the statute bars equitable relief even in suits challenging state taxes on federal constitutional grounds. ${ }^{142}$ Moreover, the state court remedy need not be injunctive, ${ }^{143}$ and usually isnot ${ }^{144}$ Thus, federal courts will allow unconstitutional taxes to be assessed and collected, even when it is certain that the state courts only offer a retrospective refund remedy. The TIA establishes a pure liability rule for constitutional rights violated by state taxation. ${ }^{145}$ Yet since its enactment in 1937 , the federal courts have never doubted its constitutionality.

An argument can be made that the TIA cases do not necessarily demonstrate that Congress could similarly block injunctions for constitutional deprivations of liberty. Taxes are paid in money, the same coin as the state refund remedy. Thus, there is little danger of undercompensation; the relevant constitutional interest is purely monetary, and thus, the legal remedy will always be as good as the equitable one. ${ }^{146}$ But the cases do not

${ }^{141} 28$ U.S.C. $\S 1341$ (2003).

142 The Brooks brothers contend that the Tax Injunction Act should not prohibit federal court jurisdiction because the gravamen of their complaint is the alleged violation of civil rights, and thus state taxability is incidental. In essence, the Brooks brothers assert that a civil rights action constitutes an exception to the specific jurisdictional bar expressed by section 1341 ... We agree with the courts that have held the Tax Injunction Act bars a civil rights action.

Brooks v. Nance, 801 F.2d 1237, 1239 (10th Cir. 1986). See Schneider Transport, Inc. v. Cattanach, 657 F.2d 128, 13 (7th Cir. 1981) ("It is well settled that allegations of deprivations of constitutional rights do not render the Act inapplicable.").

${ }^{143}$ See 1948 Revision Note (“[The] [w]ords 'at law or in equity' before 'in the courts of such State' were omitted as unnecessary."); California v. Grace Brethren Church, 457 U.S. 393, 412 \& n. 28 (1982) (holding state refund remedy available after payment under protest to be adequate).

${ }^{144}$ See Fallon, Meltzer \& Shapiro, supra note __, at 865 n.10 ("State law generally precludes state court injunctions [of allegedly unconstitutional state taxes], thus often leaving taxpayers with the choice of refusing to pay ... or ... seeking a refund after payment.").

${ }^{145}$ The TIA is not the only statute prohibiting federal courts from issuing injunctions in certain types of cases, and is probably the least well-known of such statutes. For example, the Norris-LaGuardia Act bars courts from enjoining labor strikes. See 26 U.S.C $§ 101$ (2003). However, these other statutes are irrelevant here because only the TIA is specifically aimed at prohibiting injunctions against alleged governmental encroachments on constitutional rights.

${ }^{146}$ Fallon and Meltzer have suggested this as a possible explanation for why, in the closely related context of tax refund cases, the Court has held damages to be a constitutionally required remedy that trumps the sovereign immunity that blocks money damages for other rights violations. See Fallon \& Meltzer, supra 
rest on this basis. They stand for the much broader proposition that federal courts' equity jurisdiction does not derive directly from the Constitution, and thus, there is no problem with Congress limiting plaintiffs to damage remedies for constitutional rights. This is clear from cases where courts refuse to enjoin state taxes that are alleged to violate nonmonetary civil rights, such as the privilege against self-incrimination or unreasonable searches and seizures. ${ }^{147}$ These rights are as hard to value as liberty.

Moreover, while early cases read the statutory requirement of a "plain, speedy and efficient" state court remedy as congruent with the equitable notion of "adequacy," the Court has subsequently taken a more literal approach to the statute. The Act bars federal injunctions even when the state remedy is not as robust as the equitable one. It is an "exception" to equity jurisdiction, not a codification of it. And still the Court has not found this reading of the Act to cast doubt on its constitutionality. ${ }^{148}$ The "inadequacy" requirement for equity jurisdiction is a judicial policy. Congress can legitimately trim the court's equitable powers for a much wider range of legislative policy reasons. The TIA was enacted because Congress feared injunctive relief would help taxpayers withhold large sums, thus cutting important governmental programs off from funding. ${ }^{149}$ It is hard to say that this concern is more compelling or legitimate than the arguments for denying injunctions for mass detentions.

\footnotetext{
note _, at 1826-27. ("A damages remedy for a deprivation of liberty or even of tangible property, a tax refund is nearly a perfect substitute for the money that was illegally exacted."). They reject this explanation because it would mean constitutional law privileges the redress of purely monetary rights over liberty rights, which are generally regarded as more important. $I d$. at 1827.

${ }^{147}$ Jerron West, Inc. v. California, 129 F.3d 1334, 1337 (9th Cir. 1997) (holding that TIA divests court of jurisdiction over suit where taxpayer sough injunction on grounds that assessment process would violate Self Incrimination and Search and Seizure Clauses);

${ }^{148}$ See Rosewell v. LaSalle National Bank, 450 U.S. 503, 524-27 (1981). See also, FALLON, MELTZER \& SHAPIRO, supra note __ at 1217.

${ }^{149}$ See FALlON, MELTZER \& SHAPIRO, supra note _, at 1216-17.
} 
There is one difference between this Article's pliability proposal and the TIA, but it does not amount to much. Under the latter, the court refuses to even hear equitable claims, and thus, does not rule on the constitutionality of the tax. Under the latter, the court refuses to issue an injunction after finding a constitutional violation. Thus, the TIA cases do not in themselves demonstrate that Congress can allow courts to refuse injunctions once a constitutional violation has been held tæxist.

However, the sovereign and qualified immunity call for precisely that: the remedy is denied only after the violation is found. Thus, pliability rules break no new ground by refusing to enjoin measures that have been found unconstitutional (though to be sure, the immunity doctrines themselves are widely criticized). If there is a contrary principle that violations once declared must be enjoined, despite congressional directives to the contrary - it would amount to little if Congress could circumvent it by forbidding courts from adjudicating the constitutionality of a practice in the first place. In other words, Congress's power to provide for the jurisdiction of the federal courts clearly is an area where the greater includes the lesser. If Congress can properly withhold equitable jurisdiction, it is hard to see how it could not be able to take the lesser step of withholding equitable remedies.

\section{3) Summary: a taxonomy of remedial discretion.}

Taken as a whole, the Court's jurisprudence on the right to injunctiveremedies for constitutional violations suggests a tripartite hierarchy similar to the one described by Justice Jackson in Youngstown Sheet and Tube Co. v. Sawyer. ${ }^{150}$ The analysis is much

${ }^{150} 343$ U.S. 579, 635-638 (1952) (Jackson, J., concurring). 
easier than in Youngstown, because the power of the judiciary, unlike that of the President, is not "comprehensive and undefined," 151 but rather limited and with the exception of judicial review, subordinate to Congress. In the first situation, the Court acts "pursuant to an express or implied authorization of Congress, [its] authority is at its maximum, for it includes all that [it] possesses in his own right plus all that Congress can delegate." ${ }^{152}$ The general grant of federal question jurisdiction gives the Court power to issue legal and equitable remedies, which the Court can choose among according to its lights. It can make equitable relief the default for constitutional violations; it can also, with equal propriety, use traditional equitable discretion to deny such remedies. This first class of cases is where the Court normally finds itself.

In the second class of cases, the Court acts on the background of some congressional activity, as where Congress provides for administrative relief but does not expressly rule out traditional judicial remedies. Here the Court must consider whether Congress's activity precludes particular remedies. The Court did this with respect to legal remedies in the Bush v. Lucas line of cases, and the courts of appeals have done with respect to equitable remedies in more recent cases. In these situations, some Congressional activity can implicitly strip courts of the power to enjoin conduct found to violate the constitution, though whether it does so is a tough interpretive questions.

Finally, Congress can expressly limit the availability of remedies for violations of constitutional rights. In this situation Congress gets the last word unless the remedies it bars are somehow mandated by the Constitution, or divest the Court of its constitutional

\footnotetext{
${ }^{151}$ Id. at 634 .

${ }^{152}$ Id. at 635 .
} 
powers. ${ }^{153}$ The "question of whether, or to what extent, particular injunctive remedies ... might be constitutionally required has not been sharply presented" because Congress has so rarely expressly limited them. ${ }^{154}$ The TIA is the principal instance in which Congress has denied equitable remedies for constitutional violations, and the Court's jurisprudence under the Act offer no hint of any limitations on legislative power in this regard.

The lack of a constitutional bar to liability rule protection of constitutional rights, makes it clear that a mass detention pliability rule could be implemented in several ways. Equitable discretion shows that there is nothing radical about refusing to enjoin a constitutional violation when, as in a mass detention situation, the injunction itself could cause irreparable harm. It also shows that courts can implement at least the first half of the proposed pliability rule - the suspension of equitable remedies in national security emergencies - without any kind of legislative authorization. And through the Bivens remedy, the judiciary can at least partially implement the second half of the pliability rule - the substitution of a liability rule for the temporarily suspended property rule. ${ }^{155}$ Since courts could constitutionally implement pliability through their inherent powers, Congress could a fortioriauthorize such a remedial scheme.

\section{Implicit Pliability Rules.}

While the transaction cost approach to constitutional remedies suggested by this Article may seem radical, it is in fact consistent with several venerable features of

\footnotetext{
${ }^{153}$ See id. at 637.

${ }^{154}$ FALLON, MELTZER, \& SHAPIRO, supra note _, at 856.

${ }^{155}$ The pliability rule would be work much better if implemented through legislation - which by waiving immunity would make damages easier to recover, by setting compensations schedules and allocating funds would offer a more compensatory remedy, and by specifying the triggering mechanism would ensure that the liability phase would remain the exception and not the rule.
} 
constitutional law. The Supreme Court has been attentive to transaction costs in establishing rights and remedies; it just has not expressed the issues in C\&M terms. This subpart does two things. First, it provides further evidence that when transaction costs become relatively high, property rule protection for liberty rights becomes socially inefficient and so the Court will abandon property rules. Second, this subpart unifies what were previously thought to be isolated and ad hoc constitutional exceptions, showing them all to be easily explicable through C\&M-style transaction cost analysis. However, constitutional law has not understood these exceptions in such terms, and as a result, these exceptions have the potential to expand beyond their justifiable limits. Thus,the final contribution of this subpart is to show thatC\&M analysis provides a principle for cabining these various exceptions to property rule protection of constitutional rights. In a sense, pliability rules for constitutional rights are nothing new. Quarantines, compulsory vaccination, and military conscription all deprive individuals of liberty, and yet have all been held constitutional. In these situations, a sudden rise in transaction costs triggers a suspension of property rule protection. In other words, the Court has always used pliability rules in constitutional cases. Of course, the Court does not announce that an entitlement will be protected by a property rule in some cases and a liability rule in other cases. Rather, the existence of the pliability rule emerges from decisions in which the Court holds an uncompensated taking "unconstitutional" when transaction costs are low, while finding such a taking permissible under a different set of facts characterized by significantly higher transaction costs. 
The most common of these liberty-entitlement pliability rules toggle not between property and liability protection, but between property and no protection ${ }^{156}$ However, Congress often provides at least partial compensation for the individuals subject to the taking. For example, the Supreme Court has suggested in dicta that conscripts need not be paid for their service. ${ }^{157}$ They are in fact paid, but according to the Court this due to legislative grace, not constitutional obligation. ${ }^{158}$

\section{1) Quarantines and vaccination.}

The Court has held that the government may forcibly vaccinate ${ }^{159}$ and quarantine ${ }^{160}$ people during outbreaks of infectious disease, while acknowledging the conflict between such measures and the Constitution's liberty right. ${ }^{161}$ As with mass detentions in national security emergencies, such measures sweep in those who pose no danger to society (because they are free from disease and unlikely to contract it) as well as infected people who pose a serious threat. Jacobson, the Court's leading case on compulsory public health measures, explicitly countenanced the quarantine of people

\footnotetext{
${ }^{156}$ Bell and Parchomovsky describe such rules as "zero order pliability rules." Bell \& Parchomovsky, supra note _, at 6, 30-31.

${ }^{157}$ Hurtado v. United States, 410 U.S. 578, 588-89 (1977) (using conscription to illustrate the proposition that the government need not "pay for the performance of a public duty it is already owed," and holding that a one dollar per diem for material witnesses detained pending trial is not unconstitutionally low).

${ }^{158}$ Lichter v. United States, 334 U.S. 742, 756 (1948) ("For his hazardous, full-time service in the armed forces a [conscript] is paid whatever the Government deems to be a fair.")

${ }^{159}$ See Jacobson v. Commonwealth of Massachusetts, 197 U.S. 11, $26-27$ (1905) (Harlan, J.).

${ }^{160}$ See id. at 29. See also Leisy v. Hardin, 135 U.S. 100, 145 (1890) (observing that while "quarantine laws ... restrain the liberty of the passengers [arriving in a port]" they "must of necessity have full and free operation, according to the exigency which requires their interference"). The constitutionality of state quarantine laws has been assumed for so long that that challenges to them invariable involve dormant Commerce Clause objections, not individual liberty claims. The constitutionality of federal quarantines has not been conclusively established, but the arguments for such power seem strong.

${ }^{161}$ Jacobson, 197 U.S. at 29-30.
} 
"apparently free from disease." 162 Without an actual or imminent outbreak, such public health measures require individual consent - a property rule. Because the protection of the liberty entitlement toggles from a property rule upon the happening of a discrete event marking a massive rise in transaction costs, it is clearly a form of constitutional pliability rule. While the Court has not mandated it, Congress provides compensation to those who suffer death or injury from compelled vaccination, thus creating another "classic" pliability rule. ${ }^{163}$ As Jacobson makes clear, the protection reverts to the default property rule as soon as the emergency passes. As with the mass detention pliability rule, the court reviewing a quarantine will stick with the default property rule if it concludes the triggering event has not in fact transpired ${ }^{164}$ or that the measure is implemented to oppress the targeted group rather than to ensure the public safety. ${ }^{165}$

Like national security detentions, compulsory vaccination and quarantine respond to situations where transaction costs would defeat socially beneficial measures under a property rule. The sources of the transaction costs are much the same in both situations. The measures must be implemented quickly, making one-by one bargaining or investigation infeasible. Indeed, Jacobson stesses the "imminent danger," a theme Hirabayashi wouldecho in the mass detention context forty years later. Moreover, all of the affected individuals must be quarantined to secure the social benefit; letting one

\footnotetext{
${ }^{162}$ Id. at 29.

${ }^{163}$ See 42 U.S.C. $\$ 300 a a-10$ (a) (2003) (establishing National Vaccine Injury Compensation Program). The vaccine compensation program is considerably more generous than the compensation paid to conscripts. For example, the wrongful death award is $\$ 250,000$. See $\$ 300$ aa-15(a)(2).

${ }^{164}$ See, e.g., Jew Ho v. Williamson, 103 F. 10, 26 (N.D. Cal. Cir. 1900) (suggesting in dicta that quarantine is unconstitutional because the pretext - a purported bubonic plague epidemic — appeared fictitious).

165 See id. at 23-24 (finding quarantine unconstitutional under the 14th Amendment and enjoining its enforcement because it targeted only the Chinese residents of the affected area, for no reason other than racial animus).
} 
infected person out of the quarantine zone would be enough to broadcast the contagion. As with mass detentions, all the potentially exposed people in effect jointly own the entitlement the government seeks to take. This is the paradigmatic case for abandoning property rules because of the potential for holdout problems.

Jacobson seems particularly sensitive to the problems property rules can create in high transaction cost settings. The Court notes the danger of relying during epidemics on people's "willingness to submit to reasonable regulations." 166 This sounds like concern about holdout problems, which arise when the consent requirement of property rules is maintained in high transaction cost settings. Indeed, coercive public health measures might face lower transaction costs than the national security measures because the adverse selection problem would be lower. The enemy agent would be the least likely to agree to detention, whereas someone who knows they are or are likely to become infected might submit to quarantine or vaccination at least as readily as a healthy person.

\section{2) Military conscription.}

Military conscription has "long been recognized as constitutional," 167 although it is a severe and extended depravation of liberty and potentially of life. While the Court's view that conscription falls within Congress's power to "raise . . armies" is plausible, ${ }^{168}$ the Constitution does not explicitly permit takings of liberty without criminal suspicion for military or any other purpose, and the Thirteenth Amendment expressly bans all

\footnotetext{
166 Jacobson, 197 U.S. at 29.

167 CURRIE, Supreme Court, supra note __, at 304 \& n.172 (describing arguments based on historical practice for constitutionality of the draft as "persuasive").

${ }^{168}$ See U.S. Const., art. I, § 8; Selective Draft Law Cases, 245 U.S. 366, 376-78 (1918).
} 
involuntary servitude. ${ }^{169}$ This shows, at a minimum, that the Takings Clause does not exhaust the possibilities for governmental seizures of private interests.

Conscription is a close cousin of mass detention. Both are pliability rules motivated by suddenly high transaction costs. When manpower is needed for war, property rules may not work because of extraordinarily high transaction costs. Normally, when the government needs peoples' services, even military services, it can (and therefore must) negotiate with them one by one in the labor market. When an army must be raised, it becomes impossible to simultaneously negotiate with the requisite number of people. And as with mass detentions, impending enemy action constricts the time in which individual bargaining can occur. The social cost of not transferring the liberty entitlements can be catastrophic, and so the Court permits involuntary transfers.

The federal draft's debut in the Civil War provides a clear illustration of the role played by suddenly high transaction costs. Congress enacted the draft only after voluntary recruitment failed to fill the Army's manpower quota, and crude attempts at negotiation - in the form of increasing enlistment bonuses - also failed. ${ }^{170}$ Increases in the bonus did result in increased enlistment, just not enough. So one suspect the problem was not transaction costs, but merely the government's unwillingness to pay what the market

\footnotetext{
${ }^{169}$ The Supreme Court brushed off this textual argument with one sentence and no substantive reasoning: "As we are unable to conceive upon what theory the exaction by government from the citizen of the performance of his supreme and noble duty of contributing to the defense of the rights and honor of the nation ... can be said to be the imposition of involuntary servitude. . . we are constrained to the conclusion that the contention to that effect is refuted by its mere statement." Selective Draft Law Cases, 245 U.S. at 390.

${ }^{170}$ McPherson, supra note _, at 492-93 (describing failure of bounties to fill militia draft quota).
} 
demands. ${ }^{171}$ However, arriving at the right sum would require iterative increases in the bounty. This could take some time, during which the war could be lost.

The government's only alternative under a property rule would be to overcompensate by offering an extremely high bounty. The excess payment above what individuals would demand is also a transaction cost. The market imperfection is the government's inability to negotiate directly with every potential recruit, and therefore having to guess the right level of compensation and wait to see if it brings in enough people. Still, the government could partially satisfy its manpower needs under a property rule. Recruits are fungible. If any one person did not enlisted, his neighbor would serve just as well. If voluntary enlistment only filled half the recruitment quota, the government would still enjoy substantial benefits from the services of the volunteers. Thus conscription is a weaker case for pliability than mass detentions and quarantines, where the failure to take the rights of one individual could defeat the entire social benefit and make the rest of the takings wasteful.

The Civil War draft law allowed conscripts to pay someone else to serve in their place. This "substitution" option effectively gave the job of bargaining with individuals for their liberty entitlement to the draftees themselves, who, being numerous and dispersed faced much lower transaction costs than the government would. Indeed,

${ }^{171}$ This argument was made in the appellants in Selective Draft Law Cases and rejected by the Court, but for the wrong reasons.

[I]t is said [by the defendants], the right to provide is not denied by calling for volunteer enlistments, but it does not and cannot include the power to exact enforced military duty by the citizen. This however but challenges the existence of all power, for a governmental power which has no sanction to it and which therefore can only be exercised provided the citizen consents to its exertion is in no substantial sense a power.

Selective Draft Law Cases, 245 U.S. at 377-78 Of course the Constitution's grant to Congress of the power to raise armies could just as easily be understood as making that a permissible area of governmental endeavor, without authorizing coercive means. One would not think that the congressional power to provide for Post Offices authorizes the conscription of mailmen. 
"substitute brokers" went into business to negotiate the deals. ${ }^{172}$ Moreover, men could pay their way out of the draft, with the proceeds of "commutation" funding bonuses for voluntary enlistees. ${ }^{173}$ The effect of the commutation/substitution system was to drive down transaction costs to the point that efficient transfers of the liberty entitlement were possible even under a property rule: only $22 \%$ of draftees personally served. ${ }^{174}$ Abuses during the Civil War and changes in society brought substitution and commutation into disrepute, and they were subsequently abandoned. However, as a result, the government faced massive transaction costs in filling an army during wartime. Thus,it is not surprising that the Supreme Court first upheld the constitutionality of conscription in response to the next wartime draft.

\section{3) Transaction cost limits of the conscription analogy.}

The pliability rules for public health measures and conscription demonstrate that the national security mass detention pliability rule presented in this Article fits within established constitutional jurisprudence. Indeed, when allowing a suspension of property rule protection for constitutional rights in other contexts, the Court routinely makes analogies to the draft. ${ }^{175}$ The conscription analogy has at times been taken too far. This

\footnotetext{
${ }^{172}$ See id. at 606.

${ }^{173}$ See id. at 605 . The government can be viewed as having a right to the draftees' services, a right commonly thought of as absolute but in fact protected by a liability rule. This is analogous Boomer $v$. Atlantic Cement, where the plaintiff's right to enjoin a nuisance could be purchased by the nuisance-maker.

${ }^{174}$ See id. at 601. According to McPherson, the infamous Civil War draft "was not conscription at all" but rather a clumsy "device to stimulate volunteering." Id. at 605.

${ }^{175}$ See Korematsu, 323 U.S. at 210 ("All citizens alike, both in and out of uniform, feel the impact of war in greater or lesser measure. Citizenship has its responsibilities as well as its privileges, and in time of war the burden is always heavier.").

The liberty secured by the 14th Amendment . . . consists, in part, in the right of a person to live and work where he will and yet he may be compelled, by force if need be. . to take his place in the ranks of the army of his country, and risk the chance of being shot down in its defense.
} 
could be seen as an indictment of constitutional pliability rules, as evidence that they will not be contained by their "triggering" mechanism or transaction cost rationales, and will lead down the slippery slope to rights erosion. However, the overextension of "iplicit" pliability rules stems from the Court's original failure to understand these exceptions to property rule protection as being motivated by transaction costs. Firmly securing constitutional pliability rules in $\mathrm{C} \& \mathrm{M}$ analysis, as this Article has attempted to do, should not only deter undue expansion of the mass detention pliability rule, but also reign in abuses of the "implicit" pliability rules for quarantines and conscriptions.

The peacetime draft is the most obvious example of an implicit pliability rule expanding past is transaction cost rationale. This is a consequence of courts not being sensitive to the transaction cost justification for the wartime draft. The Court justified the draft by appealing to broad notions of civic duty rather than C\&M analysis. Thus, it is not surprising that the draft expanded beyond the transaction cost setting that originally warranted it. The civic duty rationale applies equally to a peacetime draft; the transaction cost rationale does not.

Justice Holmes used conscription as a measure of constitutionality against which few governmental takings of rights, even forced sterilization, could fall short. ${ }^{176} B y$ identifying the transaction cost rationale of conscription, the pliability approach advocated in this Article also reveals the proper limits of the conscription analogy. Instead of opening the way to polymorphous governmental condemnation of individual

Jacobson, 197 U.S. at 29-30 (emphasis added) (citation omitted). Professor Currie explicitly analogizes the Japanese detainees to draftees - singled out to bear disproportionately high burdens. See CURRIE, supra note _, at 293-94 n. 99.

${ }^{176}$ See, e.g., Buck v. Bell, 274 U.S. 200, 207 (1927) ("We have seen more than once that the public welfare may call upon the best citizens for their lives. It would be strange if it could not call upon those who already sap the strength of the State for these lesser sacrifices."). 
rights, this Article's analysis instead puts such condemnation within its proper limits. These limits are narrower and more protective than the Court's rather ad hoc and opportunistic innovation of the conscription analogy.

Properly understood, the pliability approach that sanctions both mass detentions and conscription only applies to situations where bargaining with individuals will not succeed because of high transaction costs and thus imposes massive social costs. Ironically, Buck v. Bell involved the exact opposite situation. The Virginia law authorizing the sterilization of "imbeciles" required a complex, multi-tiered set of administrative and judicial proceedings to determine whether each potential victim suffers from hereditary mental illness. ${ }^{177}$ The government did proceed on a case-by case basis, and there was no evidence of either great urgency or an overwhelming number of cases. Indeed, Justice Holmes conceded this point when he claimed that sterilization was “often not felt to be [a sacrifice] by those concerned," ${ }^{178}$ suggesting an absence of holdout and adverse selection problems.

Furthermore, whatever the alleged benefits of sterilization, they would be achieved pro rata through however many voluntary transfers the government could negotiate - unlike security detentions and quarantines, it is not all or nothing. Because there were no systemic obstacles to bargaining, the proper balance between the government's health goals and the rights of the patients would have been struck by paying those who voluntarily sterilized themselves. ${ }^{179}$ Thus a pliability rule for mass

\footnotetext{
${ }^{177}$ Id. at 206.

${ }^{178} I d$. at 207.

${ }^{179}$ In no way should this be understood as suggesting that such a policy would be morally sound.
} 
detentions, unlike Holmes' misapplied conscription analogy, would not pave the way to abolishing property rule protection for all constitutional rights.

\section{CONCLUSION}

There is room in constitutional law for liability rules as well as property rules. Transaction costs do not disappear when one moves from private law entitlements to constitutional entitlements. Not surprisingly, the problems that ensue from sticking with property rules in high-transaction cost settings do not disappear either. Indeed, to the extent that constitutional entitlements are more important than private law ones, the problems of using the wrong rule to protect them are more severe. An appreciation of the full range of remedial alternatives known to private law will better equip courts to deal with these sensitive situations. Furthermore, constitutional protection need not be binary, all-or-nothing, winner-take-all. Liability rules allow for compromises between important interests to be made within a single case.

In mass detention situations, the faults of injunctive essentialism stand out in sharp relief. In these cases, property rules turn out to be a false promise, and detainees are left with no protection at all. The surprising superiority of liability rules in such cases illustrates the potential of a broader view of constitutional remedies.

Of course, property rules will generally be the right way of protecting constitutional rights. But to conclude that liability rule protection is never be appropriate for constitutional rights is, as de Tocqueville put it, to mistake the familiar for the 
necessary. ${ }^{180}$ However, the fact that liability rules will only be preferable in unusual, but disproportionately important, circumstances suggests that constitutional rights will be best served neither through pure liability nor pure property rules, but rather the more complex and flexible pliability rules, which combine a default property rule with a temporary liability rule triggered by heightened transaction costs.

\footnotetext{
${ }^{180}$ This is no less a mistake in constitutional jurisprudence than in any area of thought. See Adamson v. United States, 332 U.S. 46, 62-63 (1947) (Frankfurter, J., concurring) (citing various practices -- like trying petty cases without a jury -- as proof of de Tocqueville's maxim that while uncommon do not constitute deprivations of Due Process).
} 